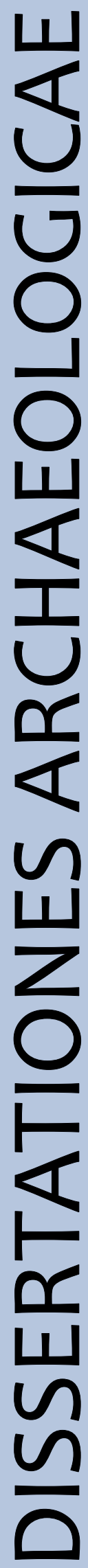

ex Instituto Archaeologico Universitatis de Rolando Eötvös nominatae
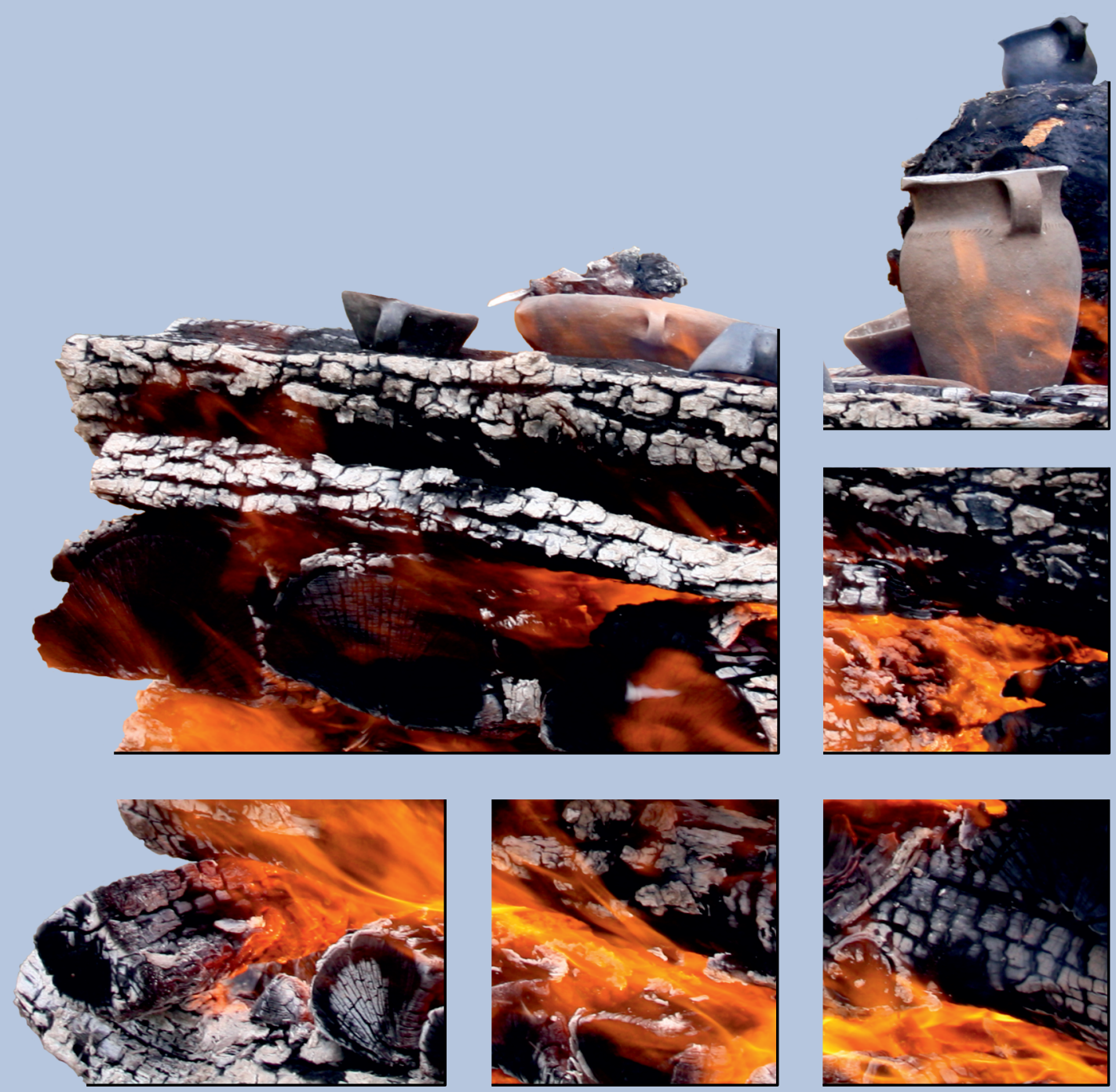

$$
\text { Ser。 3. No } 0_{0} \sigma_{0} \mid 2018
$$




\section{Dissertationes Archaeologicae ex Instituto Archaeologico}

Universitatis de Rolando Eötvös nominatae Ser. 3. No. 6.

Budapest 2018 


\section{Dissertationes Archaeologicae ex Instituto Archaeologico}

Universitatis de Rolando Eötvös nominatae Ser. 3. No. 6.

Editor-in-chief:

DÁvid BARTUS

Editorial board:

LÁsZló BARTOSIEWICZ

LÁSZLÓ BORHY

ZOLTÁN CZAJLIK

ISTVÁN FELD

GÁBOR KALLA

PÁL RACZKY

MiKLÓS SZABÓ

Tivadar Vida

Technical editor:

GÁBOR VÁcZI

Proofreading:

ZsófIA KondÉ

SzILVIA BARTUS-SzÖLLősI

Aviable online at http://dissarch.elte.hu

Contact: dissarch@btk.elte.hu

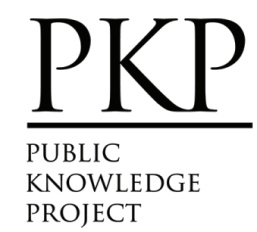

๑ E Eötvös Loránd University, Institute of Archaeological Sciences

Layout and cover design: Gábor Váczi

Budapest 2018 


\section{CONTENTS}

Zsolt Mester

In memoriam facques Tixier (1925-2018)

\section{ARTICLES}

Katalin SEBőK

On the possibilities of interpreting Neolithic pottery - Az újkökori kerámia értelmezési lehetőségeiről

András FüZESI - Pál RACZKY

Öcsöd-Kováshalom. Potscape of a Late Neolithic site in the Tisza region

Katalin SEBőK - Norbert FARAgó

Theory into practice: basic connections and stylistic affiliations of the Late Neolithic settlement at Pusztataskony-Ledence 1

Eszter Solnay

Early Copper Age Graves from Polgár-Nagy-Kasziba

László GuCsi - Nóra Szabó

Examination and possible interpretations of a Middle Bronze Age structured deposition

Kristóf FÜLÖP

Why is it so rare and random to find pyre sites? Two cremation experiments to understand the characteristics of pyre sites and their investigational possibilities

Gábor János TARBAY

"Looted Warriors" from Eastern Europe

Péter MogYoRós

Pre-Scythian burial in Tiszakürt

Szilvia JoHÁczi

A New Method in the Attribution? Attempts of the Employment of Geometric Morphometrics in the Attribution of Late Archaic Attic Lekythoi 
The Roman aqueduct of Brigetio

Lajos JuHÁsz

A republican plated denarius from Aquincum

Barbara HAJDU

Terra sigillata from the territory of the civil town of Brigetio

Krisztina HoppÁL - István VIDA - Shinatria AdHityatAma - Lu Yahui 461

'All that glitters is not Roman'. Roman coins discovered in East Java, Indonesia.

A study on new data with an overview on other coins discovered beyond India

\section{FIELD REPORTS}

Zsolt MESTER - Ferenc CSERPÁK - Norbert FARAGÓ

Preliminary report on the excavation at Andornaktálya-Marinka in 2018

Kristóf FÜLÖP - Denisa M. LÖNHARDT - Nóra SZABÓ - Gábor VÁcZI

Preliminary report on the excavation of the site Tiszakürt-Zsilke-tanya

Bence Simon - Szilvia JohÁcZI - Zita KIS

Short report on a rescue excavation of a prehistoric and Árpádian Age site near Tura

(Pest County, Hungary)

Zoltán CzAJlik - Katalin NovinszKi-Groma - László RupNIK - András BöDőcs - et al. 527

Archaeological investigations on the Süttö plateau in 2018

Dávid BARTus - László BORHY - Szilvia JoHÁczi - Emese SzÁMADó

Short report on the excavations in the legionary fortress of Brigetio (2017-2018)

Bence Simon - Szilvia JoháczI

Short report on the rescue excavations in the Roman Age Barbaricum near Abony

(Pest County, Hungary)

Szabolcs Balázs NAGY

Recent excavations at the medieval castle of Bánd 


\section{Thesis Abstracts}

Rita JENEY

Lost Collection from a Lost River: Interpreting Sir Aurel Stein's "Sarasvatī Tour" in the History of South Asian Archaeology

István VIDA

The Chronology of the Marcomannic-Sarmatian wars. The Danubian wars of Marcus Aurelius in the light of numismatics

Zsófia MASEK

Settlement History of the Middle Tisza Region in the $4^{\text {th }}-6^{\text {th }}$ centuries AD.

According to the Evaluation of the Material from Rákóczifalva-Bagi-földek 5-8-8A sites

Alpár Doвоs

Transformations of the human communities in the eastern part of the Carpathian Basin between the middle of the $5^{\text {th }}$ and $7^{\text {th }}$ century. Row-grave cemeteries in Transylvania, Partium and Banat 


\title{
Theory into practice: basic connections and stylistic affiliations of the Late Neolithic settlement at Pusztataskony-Ledence 1
}

\author{
KATALIN SEBŐK \\ Institute of Archaeological Sciences \\ Eötvös Loránd University \\ sebokkata@gmail.com
}

NORBERT FARAgÓ

Institute of Archaeological Sciences

Eötvös Loránd University

norbert.farago@gmail.com

\begin{abstract}
Despite being positioned in the western fringes of the Tisza culture's occupation area, the Late Neolithic settlement at Pusztataskony-Ledence 1 is seemingly well separated from the communities of the Lengyel complex. The character of its archaeological record however, together with recent results in the research of connections between the two cultural complexes raises the possibility of an amalgamation of these traditions at some point. In 2016, a grant of the National Research, Development and Innovation Office allowed us to start a threeyear-long project, aimed to process the data gained at Pusztataskony over three seasons in order to reveal foreign cognitive elements in the archaeological record of the site other than the ones observed in the burials. To match possible population movement with the appearance of Lengyel type cultural traits and understand the situation observed here classical archaeological and bioarchaeological analyses had been carried out. The current study surveys the first results of the investigations focusing on the archaeological record from one of the house clusters in the settlement. The examinations include a basic typological and resource analysis of the lithics and a stylistic analysis of the ceramic material. The interpretation focuses on the site's contact system as outlined by the archaeological record, on the ceramic inventory as a medium of everyday symbolic communication here, as well as on our recent understanding of the character of contacts between the Tisza and Lengyel populations in the Middle and Upper Tisza Region.
\end{abstract}

\section{Introduction}

In 2007, a new multiperiod site was discovered in the Middle Tisza Region as part of the investigations related to an impact study analysing the archaeological concerns of a planned artificial reservoir (Fig. 1.1-2). The site is positioned on a high bank on the outer side of a large curve of the Tisza, stretching on the highest parts in the neck of a peninsula-like geological formation that must have been the first flood-free elevation before the regulation of the riverbed in the 19th century (Fig. 1.3-4). Amongst the mainly residential phenomena of 7 periods $^{1}$ and the burial grounds of 4 others ${ }^{2}$ lay an extended horizontal settlement of the Late Neolithic Tisza culture. The path of the reservoir's inflow channel was designed to run along the top of this floodfree bank, allowing us to unearth a 72-meter-wide, complete longitudinal cross-section of the site's riverside zone. The fieldwork was conducted by the Archaeological Institute of the Eötvös Loránd University, and carried out in three consecutive seasons between 2009-2011.

1 Linear Pottery culture (2-3), Szakálhát culture, Tisza culture, Tumulus culture, Gáva culture, Scythians $\left(7^{\text {th }}-\right.$ $6^{\text {th }}$ century BC), Sarmatians, early Avar period, as well as irrigation channels dated to the $17^{\text {th }}-18^{\text {th }}$ centuries AD (FüZESI - SEBők 2009, 367-368; FÜZESI et al. 2010, 377-379).

2 Tiszapolgár-Bodrogkeresztúr culture, Gepids, early Avar period, late Avar period, as well as a stratum with unidentified prehistoric skeleton burials (FÜZESI - SEBőK 2009, 367-368; FÜZESI et al. 2010, 377-379). 

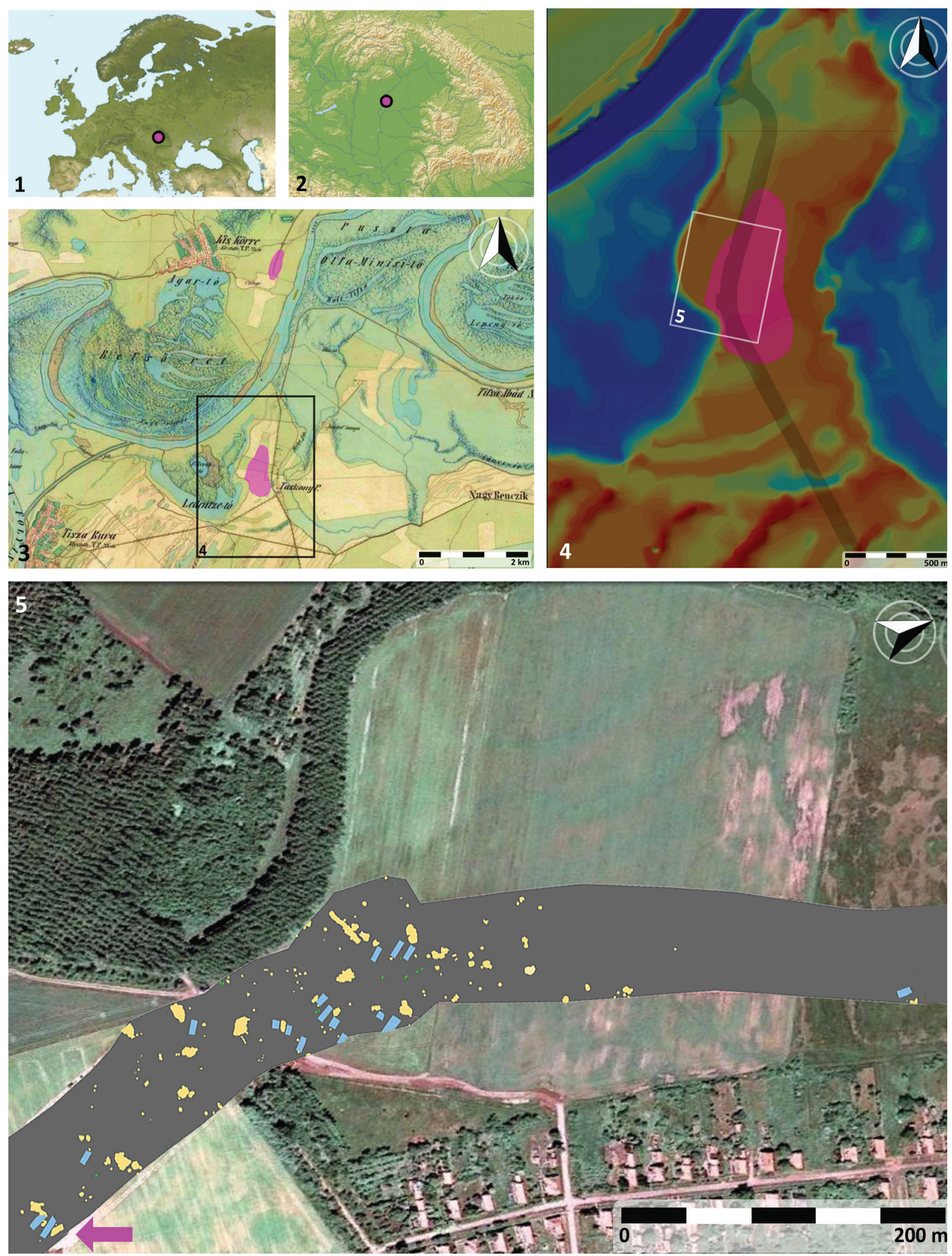

Fig. 1. Pusztataskony-Ledence 1. 1-2 - location of the site, 3 - the site and its northern neighbour, Kisköre-Gát (in pink) on a map of the Second Military Survey, 4 - elevation map (courtesy of Ágnes Király) of the peninsula between 'Ledence Lake' and the bed of the Taksony stream with the location and probable extensions of the site (in pink). The grey shadow is marking the path of the inflow channel; 5: survey map of the unearthed Late Neolithic features on a photo by Google Earth ${ }^{\mathrm{TM}}$. Blue: buildings; yellow: pits; green: burials. A pink arrow shows the southernmost house cluster. 
The excavated part of the Late Neolithic settlement is around 5.47 ha (4.22 with the major gap between phenomena in the northern zone excluded), representing its western, riverside part and fringes (Fig. 1.5). The total extension of the former settlement cannot be properly estimated, as major areas in its northern and eastern zone lay on a currently non-researchable territory (pastures, forested and built-up areas). A comparison of available data - the distribution of the unearthed archaeological phenomena, fieldwalking data from the impact study, and a map showing pristine hydrogeological relations - suggests that the central part of the Late Neolithic settlement was probably on one of the highest points of this peninsula, next to a small, protected, baylike curve of the habitable area, with an observable recession in the density of residential features towards inland. An amalgamation of the above-mentioned data allows a rough estimation of extension between at least 19 to 30 ha or more, meaning, also, that a part of only about $18-29 \%$ of the settlement was excavated (Fig. 1.4).

Considering the area's environmental conditions it is not surprising that the Late Neolithic features were heavily destroyed by later phenomena in the central-riverside zone, leaving us with significant uncertainty regarding the reconstructed settlement pattern (Fig. 1.5). Of the 8 observed house groups in the excavated area 5 are located in this zone with the majority of the identified residential buildings (13 of 17), but the high number of undateable, partial buildings and single postholes here, ${ }^{3}$ as well as the presence of two burials at the western edge with no identified residential features near them suggest an estimation of about 25 to 30 residential buildings to be more correct.

The settlement's inner structure seems to be rather homogenous, consisting of separate house clusters: irregular rows of residential buildings with some pits of diverse size, and occasionally a few burials around them. The completely identified houses are timber-framed surface constructions of about 11-13 by 4-5 m, with three 3-posthole rows, completed by, in some cases, a post-supported auxiliary construction on either end. There are also about five identified buildings with only two rows of postholes, but this is deemed to be a result of limited observability rather than the presence of an individual building type at the settlement. The closest analogies of this settlement structure may be found on coeval settlements in the Middle and Northern Tisza Region: the neighbouring Kisköre-Gát, ${ }^{4}$ and Polgár-Csőszhalom-dűlő. ${ }^{5}$ Just like Kisköre-Gát, this settlement seems to be poor in wells: only one was unearthed during the three excavation sessions.

On the excavated part of the settlement altogether 15 coeval phenomena contained human remains. 14 of these were regular single-grave skeleton burials of both men and women, representing all age groups, while in one case a possibly mutilated body of an adult was thrown into the bottom of a pit (Feature 2-89.217). The funerary rite of the burials seemed to follow the Tisza culture's tradition regarding all major traits (including selectiveness) but one: the addition of funerary vessel sets, a custom characteristic to early Lengyel communities.

The mixed cultural character of the site became conspicuous already at a very early stage of investigations, as it was clearly reflected not only by the local funerary practice but by the ceramic

3 Poor observation conditions also worsened the identification of postholes in this area: plough marks and washed-in topsoil patterned the clay subsoil layer, eradicating pale soil stains of pristine postholes.

4 KovÁcs 2013, 10-11. táblák.

5 Anders - RAczky 2011, 81-82, 2-3. kép; Raczky - Anders 2006, 22, 25, Fig. 3. 
material as well. ${ }^{6}$ In 2015, a project was started with the financial help of the National Research, Innovation and Development Office (OTKA PD 116711) to process the Late Neolithic record of the site, and especially to reveal the character of the early Lengyel culture's strong presence in this basically Tisza-type cultural environment through a processing and comparative analysis of available archaeological sources including archaeozoological and bioarchaeological data and lithics, and involving a stylistic and technological analysis of the ceramic material as well. Though the full processing is not yet complete, even partial results may be of interest.

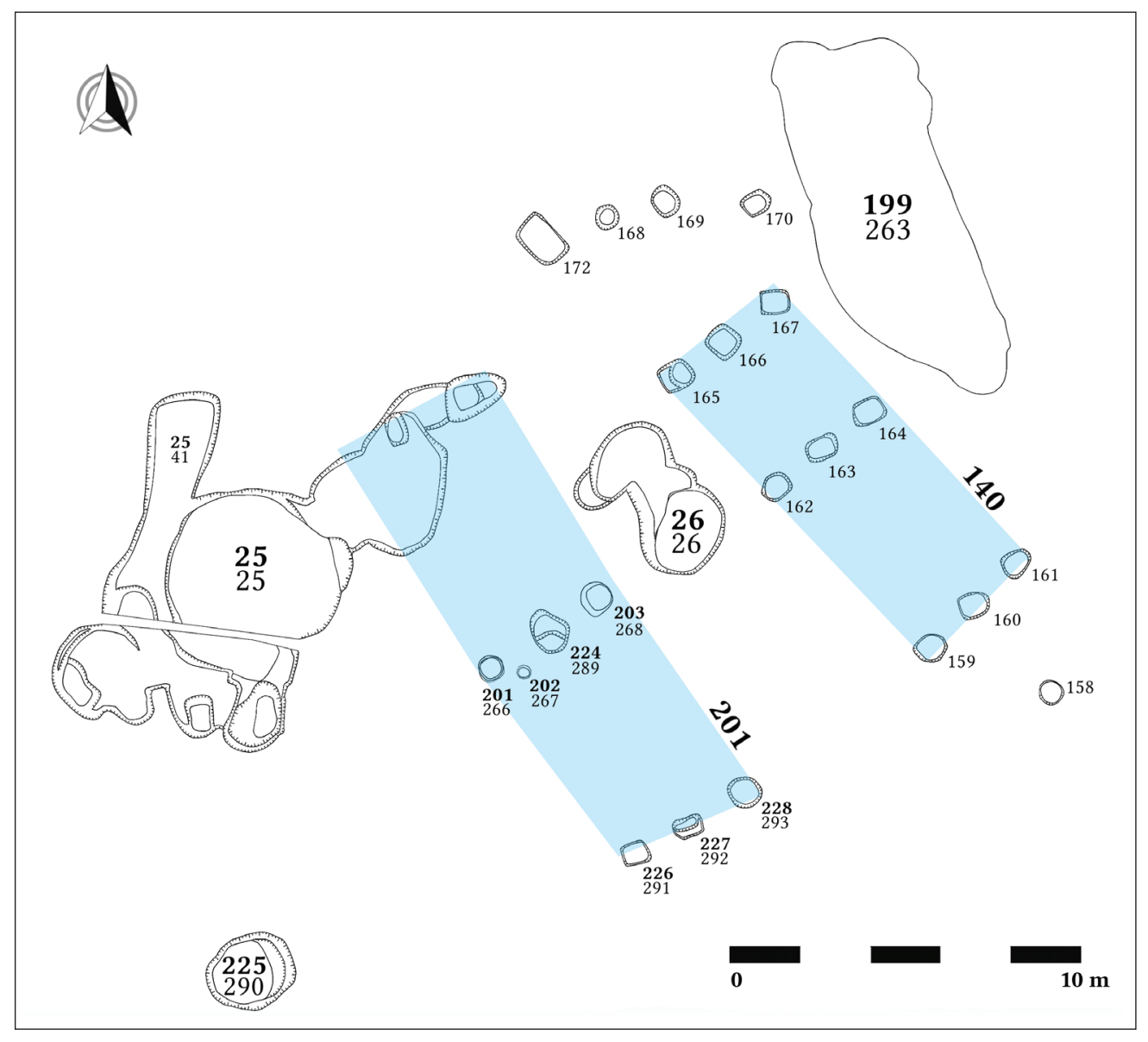

Fig. 2. Survey map of the southernmost house cluster.

The southernmost house cluster was chosen to show some preliminary results (Fig. 2). This unit is positioned on the original Pusztataskony-2 part of the settlement; ${ }^{7}$ unlike other clusters, it is well isolated in spatial terms and completely undisturbed by phenomena of other archaeological periods. Just like almost every cluster on the site, this one is also only partially unearthed: according to the distribution of the associated phenomena it is most probably continuing northeast of the excavated area. The unearthed part comprises two standard residential

6 SЕво̋к 2012, 113-114.

7 The site was defined by the preceding impact study as two separate units, (Tiszabura)-Pusztataskony-Ledence 1 and 2. In the course of the excavations their togetherness became clear, and in 2011 the $\mathrm{KOH}$ (NOCH, National Office of Cultural Heritage) united them under the name (Tiszabura)-Pusztataskony-Ledence 1 (KOH/NOCH ID: 56 131), a name to be used henceforth. As this resulted doublings in the field documentation, the number of the original parts is always marked (e.g. Feature 1-17). In the volumes of 'Régészeti Kutatások' (Archaeological Investigations) the name of the site was misleadingly published as 'Tiszabura-Ledence' by the editors' decision (FÜZESI - SEвŐK 2009, 367-368; FÜZESI et al. 2010, 377-379). 
buildings (2-141, 2-201), two larger pit-complexes (2-25, 2-199), two lesser pits (2-225, 2-226), and two uncontexted postholes (2-140), but no burials. Every feature that yielded a sufficient sample was dated - regrettably, this only means the three major pits.

Disarticulated animal bone samples were taken for AMS dating from Features 2-25, 2-26, and 2-199. The processing and evaluation of the samples was carried out by the Poznan Radiocarbon Laboratory (Fig. 3). The results were calibrated using the IntCal13 calibration curve ${ }^{8}$, with Oxcal 4.3.2. ${ }^{9}$ As there was no observed stratigraphic connection between the features, the data were rendered in one sequence in a single phase. Based on the results the life on this part of the settlement started probably around 4860 (68.2\%) $4715 \mathrm{cal} \mathrm{BC}$, lasted for about $45(68.2 \%)$ 195 years, and ended approximately around 4695 (68.2\%) 4515 cal BC (Fig. 4).

\begin{tabular}{|l|l|l|l|l|l|l|l|}
\hline Lab. No. & Feature & $\begin{array}{c}\text { Strat. } \\
\text { No. }\end{array}$ & $\begin{array}{c}\text { Radio- } \\
\text { carbon } \\
\text { age (BP) }\end{array}$ & $\begin{array}{c}\text { St. } \\
\text { dev. }\end{array}$ & $\begin{array}{c}\text { Modelled } \\
\text { date }(B C) \\
(68.2 \%)\end{array}$ & $\begin{array}{c}\text { Modelled } \\
\text { date (BC) } \\
(95.4 \%)\end{array}$ & Sample species \\
\hline Poz-47420 & 25 & 25 & 5730 & 50 & $4715-4590$ & $4725-4500$ & cattle (Bos primig.) tibia, diaph. Sin. \\
\hline Poz-97303 & 199 & 263 & 5870 & 40 & $4770-4690$ & $4825-4615$ & red deer (Cervus elaph.) carpale rad. dex. \\
\hline Poz-97304 & 26 & 26 & 5800 & 40 & $4720-4625$ & $4770-4555$ & red deer (Cervus elaph.) ph. II. ant/post. \\
\hline Poz-97305 & 25 & 25 & 5900 & 40 & $4785-4705$ & $4845-4680$ & cattle (Bos primig.) sim. frg. \\
\hline
\end{tabular}

Fig. 3. Radiocarbon measurements from Pusztataskony-Ledence 1.

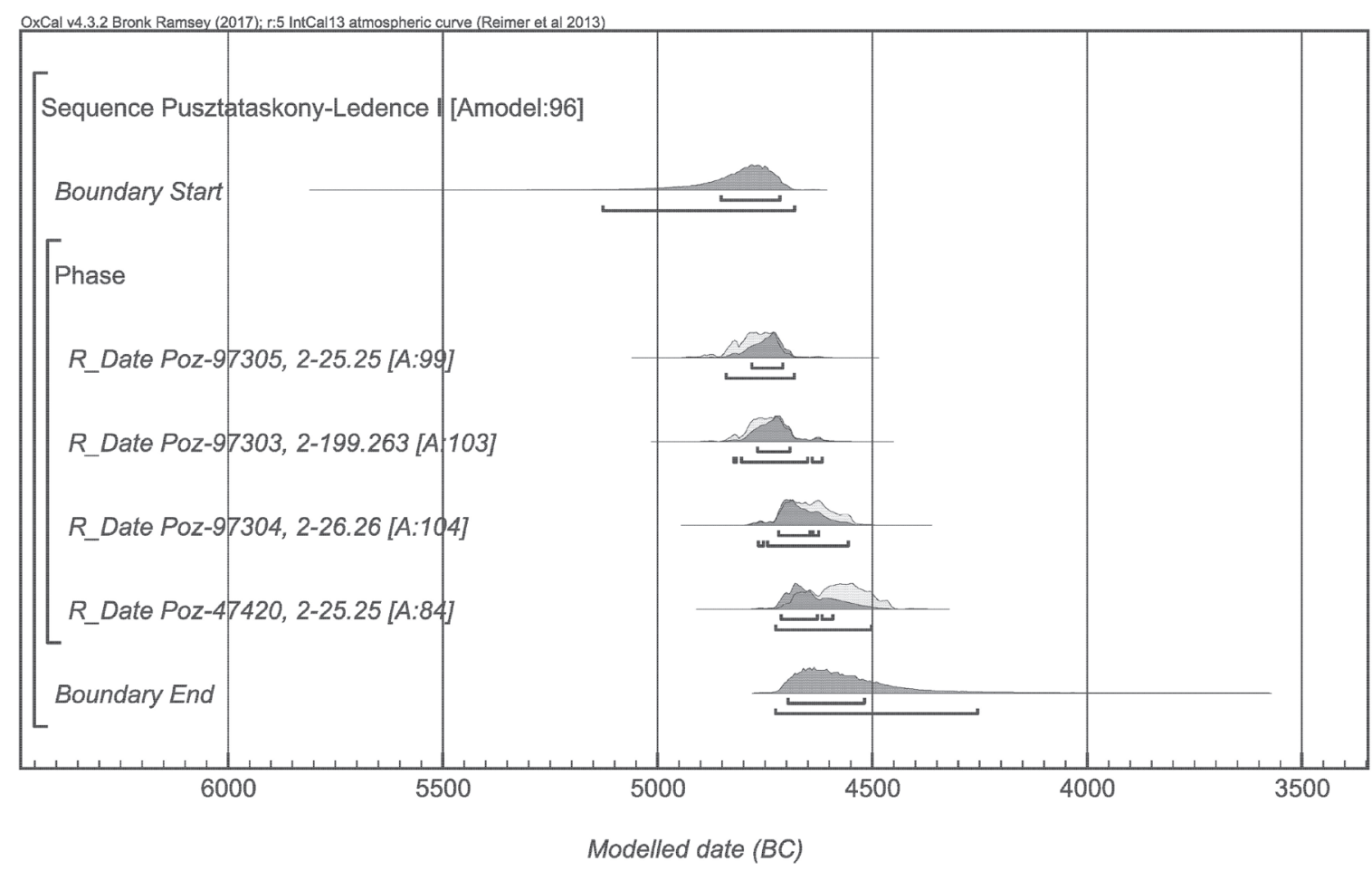

Fig. 4. Probability distributions of radiocarbon dates from the southern part of the settlement at Pusztataskony. The model is defined exactly by the square brackets down the left-hand side along with the OxCal keywords (by Zsuzsanna Siklósi).

8 REIMER et al. 2013.

9 BRonk RAMSEY 2009. 
The main goal of the current investigation was a basic characterization of the observed Lengyel presence, as well as a definition of its possible origin, obtained by an analysis of the archaeological record of the selected features. The applicable find material in this case included pottery and lithics, these being the available data sources with the capability to reveal cultural affiliations and/or exchange connections of this community.

\section{Ceramic analysis}

The ceramic material yielded by the selected features is regular household waste; no special contexts were observed here during the excavation. The stylistic analysis of the ceramic record was constructed based on a previous study on the coeval material of Polgár-Csőszhalom-dülő, a source with several resemblances. ${ }^{10}$ That situation had an essential difference from the current one: there the basic constitution and the type set of the ceramic inventory were also in question, as was the number and identity of participants of the cultural interaction. This required the introduction of a preceding analytic phase, the goal of which was the determination and description of vessel types in the local inventory.

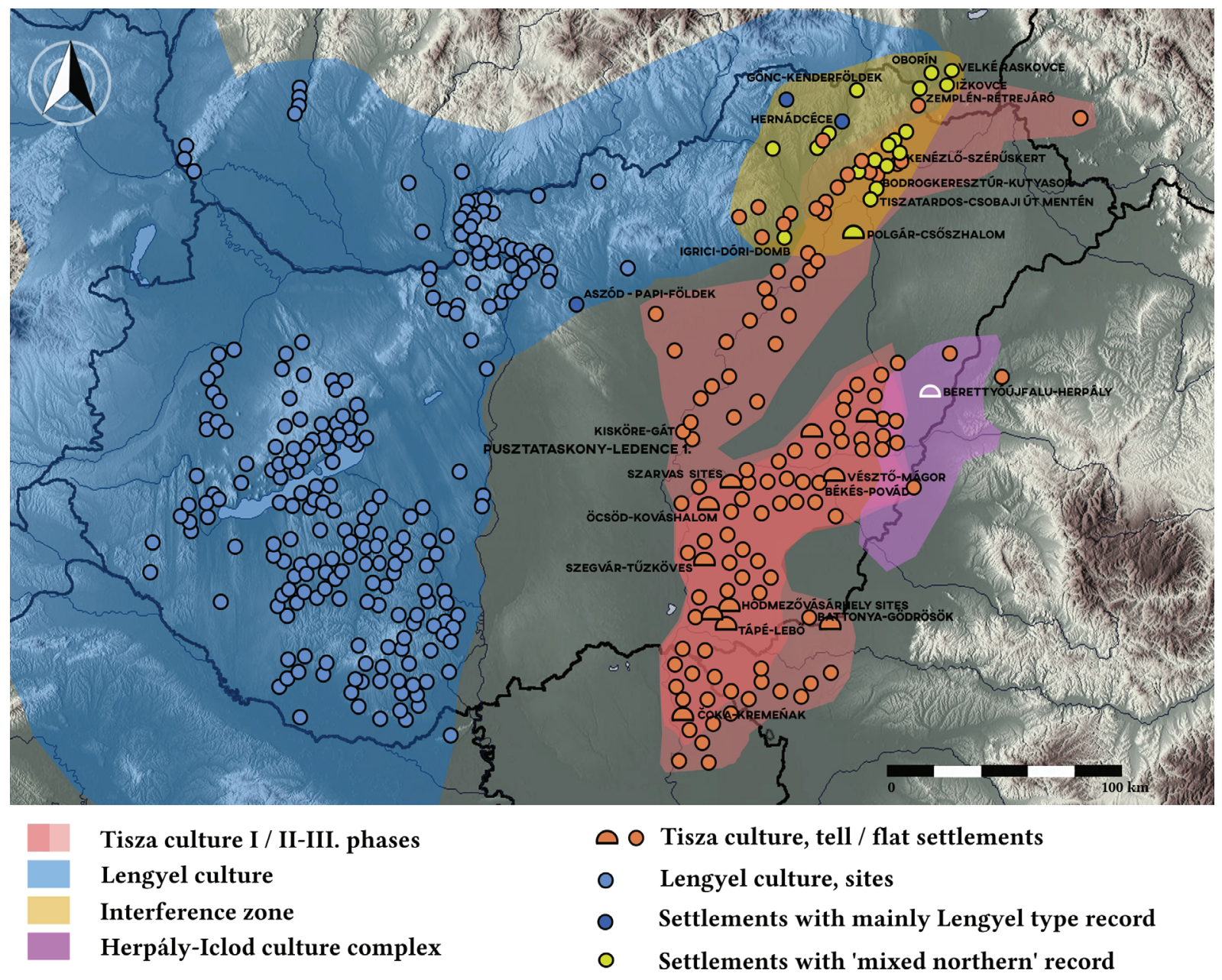

Fig. 5. Inhabitation area and site distribution of the cultural complexes involved, and the location of the sites referred to in the study. The map displays sites from all phases of the relevant cultural units. Based on Diaconescu 2014, Fig. 1; L. Hajdú 2014, 1. kép; TÁlas - Raczky 1987, map 1.

10 RACZKY ET AL. 2015, 25-31. 
As the ceramic record of Pusztataskony is clearly based fundamentally on the region's local, early Tisza traditions (Fig. 5), there was no need for a preceding type determination (as the majority of the types present fit into already set categories). The starting variable set of the stylistic database was thus compiled based on a standard 'northern' Tisza-type set as learned previously from investigations of the ceramic inventories of Kisköre-Gát ${ }^{11}$ and the settlements north of it $^{12}$ (including the relevant types of Polgár-Csőszhalom) ${ }^{13}$ During the fill up, whenever a foreign or uncategorized piece turned up, we started to search for matches in the early Lengyel culture's inventory, our main suspect, and included these variables in the existing set. The idea was to find clear matches and to create separate categories for anything new, may it be a 'hybrid' example, a new type, or a local variation of an already existing one. The type definitions included descriptions of shape, size range, applied technology, and decoration as patterns and decoration techniques.

The analysis was constructed in order to answer specific primary questions, which were:

- the constitution of the local inventory, frequency of types,

- the distribution and frequency of types representing a foreign tradition,

- the observation and description of one-time and recurring deviations as well as hybrids (types or one-time occurrences exhibiting a stylistically mixed character).

The number of occurrences was recorded by stratigraphic units.

\section{Fragmentation}

The features under study yielded altogether 7856 ceramic fragments. Of these, 1966 fragments belonging to 1541 vessels provided more than basic technological information, while a typological identification of some grade was only possible in 833 cases $\left(11 \%\right.$ / 54\%). ${ }^{14}$ The material's overall fragmentation index is 1.27 , which corresponds with the value (1.24) of a similar series from Csőszhalom. ${ }^{15}$

\section{Typology}

Regarding typology, our expectations were based mainly on two sources, none of which counts as a perfect match from a statistical point of view.

Kisköre-Gát was an obvious basis for comparison for two reasons. The first one is its vicinity in both spatial, stylistic and probably temporal terms. It was located on top of a small elevation on the opposite (right) bank of the Tisza, only $3.3 \mathrm{~km}$ away (Fig. 1.3). ${ }^{16}$ Little is known about its original extensions: it was greatly disturbed by flood protection works during the

11 KoneK 1973a, 15-17. táblák; KovÁcs 2013, 61-64. táblák.

12 KoreK 1973a; KovÁcs 2013; L. Hajdú 2015.

13 L. Hajdú 2015, 84-90, 2-15. kép; Korek 1973a, 22-41. táblák; KovÁcs 2013, 159-197, 17-22, 27-65, 85-88. táblák; SЕво̋к 2007, 98-109, Figs 1-7.

14 The analysis is vessel-based; fragmentation data are only used here, taken the character of the sample into consideration, to emphasize the limitation of the results.

$154629 / 3713=1.2467$. RACZKy et al. 2015, 25.

16 The location of the pristine settlement was reconstructed by comparing the description and excavation survey map in KOREK 1973b with descriptions in the data archive of the former National Office of Cultural Heritage as well as the relevant maps of the Second Military Survey. The accuracy of the positioning is probably less than $20 \mathrm{~m}$, the original size of the settlement is estimated based on Korek's observations and available topographic data. The former site's location is currently partially under the waterside building of the power plant, partially in the riverbed north of it. 
$19^{\text {th }}$ and the early $20^{\text {th }}$ centuries, and the rest, except for a part of about $3000 \mathrm{~m}^{2}$, excavated by J. Korek in the '60s, became destroyed during the construction works of the Kisköre power plant. ${ }^{17}$ Available data suggest that (compared to Pusztataskony) it must have been a significantly smaller settlement. ${ }^{18}$ In lack of AMS data from Kisköre-Gát, currently only stylistic information is at hand to estimate its relative position to our site, which is but a rough and fundamentally unreliable method. ${ }^{19}$ Preliminary investigations showed a pronounced similarity between the inventories of the two settlements with the occurrence of a number of the same type variants, which perhaps also suggests some grade of contemporaneity in this case. The inventory of Kisköre-Gát follows the Tisza culture's pottery tradition: it is characterized by pedestalled and flat-based biconical bowls with vertical or slightly inward-inclining walls, two-handle jugs and jars with an oval body or high shoulder, flowerpot variants, lesser biconical vessels, and containers..$^{20}$ In a sharp contrast with the ceramic material of the southern inhabitation area of the culture with tell settlements, ${ }^{21}$ the appearing type variants at KisköreGát are somewhat curvy, with less pronounced carinations. ${ }^{22}$ This 'softness' of shapes is an overall characteristic of the ceramic record of settlements with Tisza tradition both in this region and north of it (e.g. Bodrogkeresztúr-Kutyasor, ${ }^{23}$ Tiszakeszi-Szódadomb, ${ }^{24}$ Szerencs-Taktaföldvár, ${ }^{25}$ Tiszatardos-Csobaji út mentén $\left.{ }^{26}\right)$. Kisköre-Gát is only emerging from amongst these as it is significantly more well-researched and -documented than the others: this is practically the only early classical Tisza site in the culture's northern inhabitation area where a relatively well-documented, large-scale excavation was ever conducted. Still, the feasibility of the available results in the context of a statistical evaluation is rather limited, as all relevant publications focus on the reconstruction of an inventory in terms of a set of occurring type variants, while refraining, for different reasons, from quantitative analyses. ${ }^{27}$

The ceramic record of the horizontal settlement of Polgár-Csőszhalom offered both a better and a worse basis for comparison. This settlement lays in a distance of $65 \mathrm{~km}$ to the northeast, on the same bank of a pristine arm of the Tisza. A relatively recent large-scale excavation yielded an excellent source material, which was processed with an earlier version of the same statistical method that is used here. The diverse character of the cultural situation, as learned from the ceramic analysis, is what is making it less than a perfect match: while at Pusztataskony

17 Korek 1973b, 8; KoReK 1989, 23.

18 KovÁcs 2013, 40.

19 SЕво̋к 2012, 111-113.

20 KovÁcs 2013, 61-64. táblák.

21 Or rather the lack of sharp, carinated types - a phenomenon marking perhaps the stylistic point of departure from the original (southern) inhabitation area preceding the northward expansion of some groups. It must be underlined however, that such a distinction can only be done based on impressions, thus its relevance is necessarily limited: currently there is no clear publication available on the ceramic inventories of any of the culture's major tell settlements, and the arbitrary selections presented in diverse studies are usually compiled from different strata (periods) of these settlements, mostly giving a misleading impression on the overall character of their inventories. E.g. Tápé-Lebő: Korex 1958, Trogmayer 1957; Hódmezővásárhely-Gorzsa: HoRvÁTH 2005, 8-14. kép; Hódmezővásárhely-Kökénydomb: BANNer - KoreK 1949, 1-9. táblák; Szegvár-Tűzköves: CsAlog 1958, KoReK 1973a, 42-51. táblák; Vésztő-Mágor: Hegedűs - MAKKAy 1987.

22 KovÁcs 2013, 61-64. táblák.

23 KovÁcs 2013, 17-22. táblák.

24 KovÁcs 2013, 86-88. táblák.

25 KoREK 1973a, 34-36. táblák.

26 L. Hajdú 2015, 9-13. táblák.

27 Mainly because the state and/or amount of the available source material does not allow such analyses to be carried out: KoreK 1973a; KoneK 1973b; KovÁcs 2013; etc. 


\section{BOWLS}
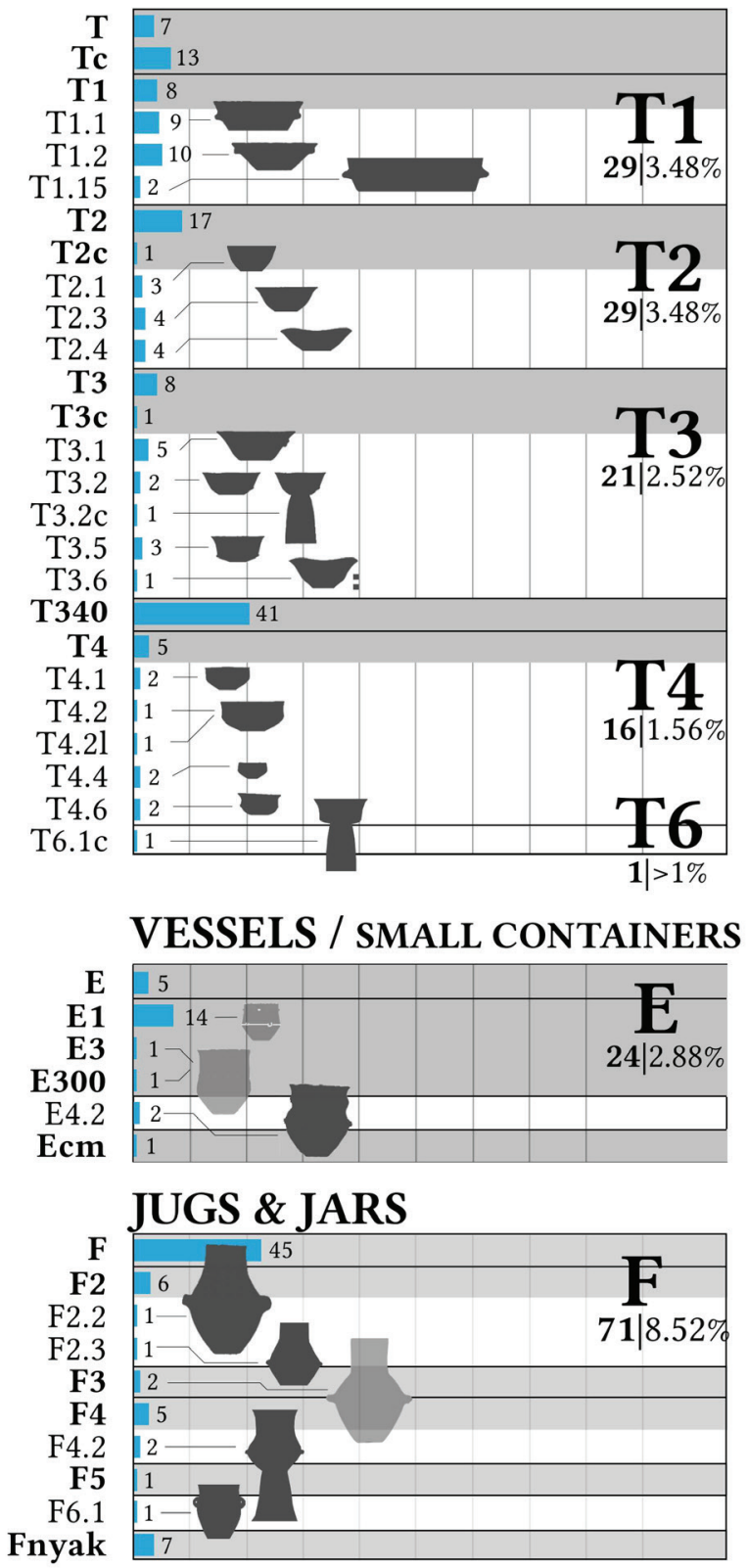

\section{FLOWERPOTS}

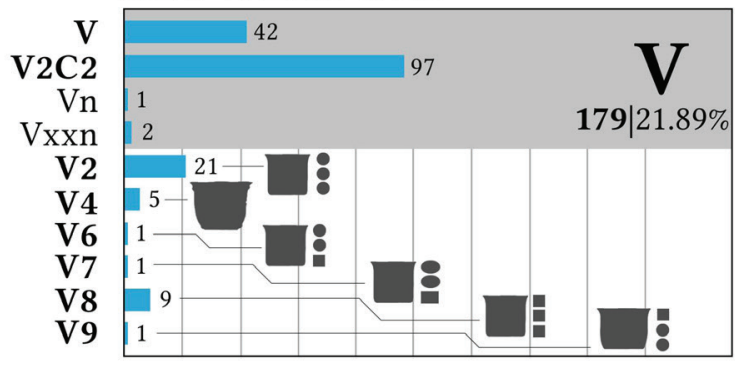

\section{CUPS}

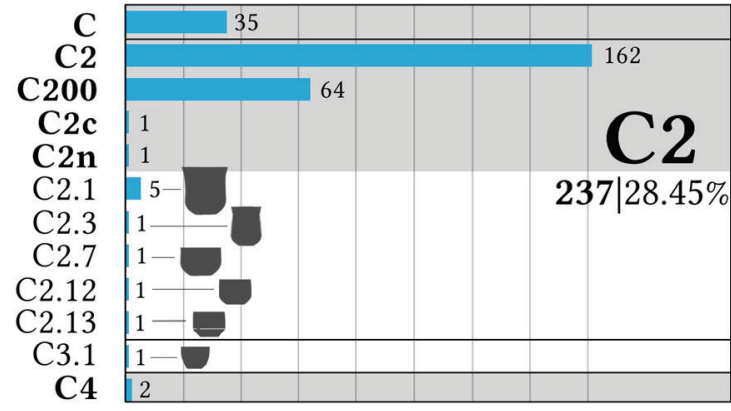

\section{BINS / LARGE CONTAINERS}

H

LIDS

L2
L3.5

3

\section{BASE FRAGMENTS}

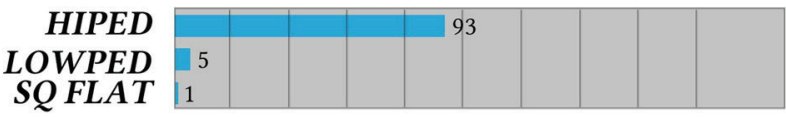

\section{LENGYEL / CUPS}

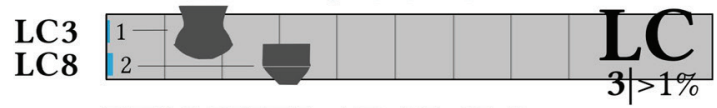

\section{LENGYEL / BOWLS}

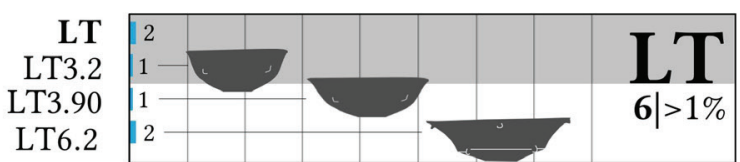

Fig. 6. Typological chart of the ceramic record of the southernmost house cluster in Pusztataskony-Ledence 1.

the presence of only two diverse traditions was detected, in the material of Csőszhalom more than five are present. ${ }^{28}$ In this latter situation, the Tisza tradition only prevails as a (major) component, sustained in a somewhat distorted form, while at Pusztataskony it seems to be a strong basis, coloured in some way by Lengyel elements - the question is, how.

The analysis of the southern cluster's ceramic record revealed a type distribution with pronounced deviations compared to the expected at several points (Fig. 6). This difference is not

28 Beside a strong autochtonous component Tisza, Herpály-Iclod, perhaps Foieni, Lengyel, Samborzec-Opatów, Stichband, and Moravian Painted elements appear in various quantities (RACZKY et al. 2007, 61-64; RACZKY SЕво̋к 2014, 81-82; RACZKy et al. 2003, 841-843). 
manifested on the primarily functional type group level, where the distribution mainly concurs with the results of a similar unit at Polgár-Csőszhalom: bowls take approximately $16 \%$ (at Csőszhalom this is 11\%), cups 18\% (25\%), vessels 14\% (6\%), jugs and jars 5\% (3\%), while bins and lids equally remain under $1 \%(>1 \%)$. The relatively high number of high pedestal fragments (93) is suggesting an even higher number for bowls, i.e., a higher proportion for pedestalled type variants among bowls. To unfold the character of the minor differences reflected even in this level, a much finer approach is required.
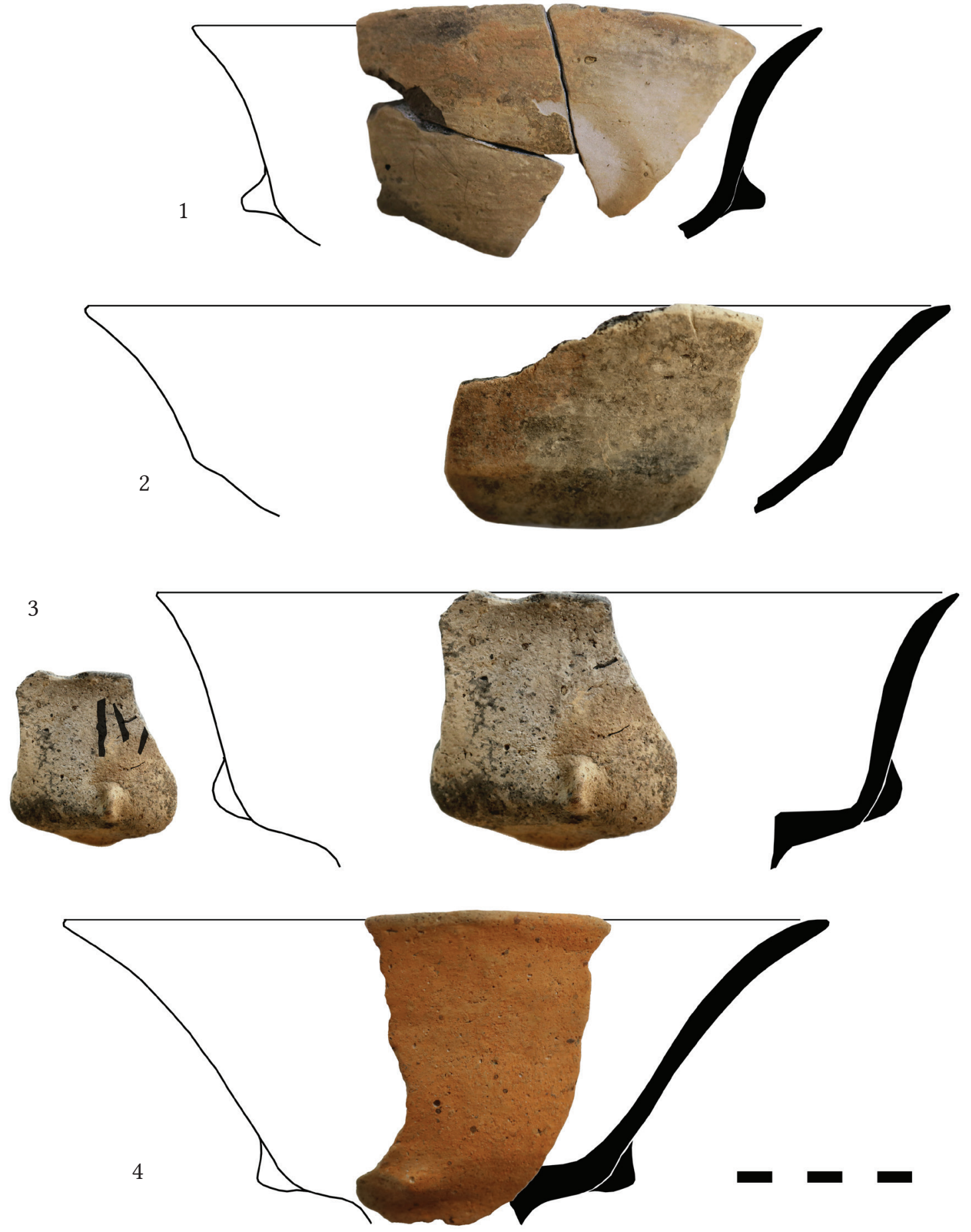

Fig. 7. Biconical bowls in the ceramic record of Pusztataskony-Ledence 1. 1 - feature 2-26.26, 2 - feature 2-25.25, 3-4 - feature 2-199.263. ID: 1 - 2010.4.026.156, 2 - 2010.4.025.336, 3 - 2010.4.199.711, $4-2010.4 .199 .644$. 
One of the differences reflected on the type group level is a relatively high proportion of vessels. A glimpse on the type level reveals a possible explanation for this: the majority of occurrences in the vessel group belong to flowerpot-shaped vessels (128/190 of 214). ${ }^{29}$ This seeming abundance of flowerpots may be due at least to two factors. First, in the case of flowerpots, a durable, incised decoration is an inseparable part of the type (i.e., there are no undecorated examples), which eases type identification considerably even when the material is highly fragmented, but also causes an incalculable distortion among types. But even with this probable effect taken into account, the numbers still remain high: the values for the same category in the Csőszhalom material are only 77 of 214 . As for the flowerpot type variants at Pusztataskony, about the third of the identified ones represents a variant with more-or-less quadrangular cross-section or mouth (Fig. 16.1-2, 5). Similar vessels sometimes appear in the ceramic record of northern Tisza settlements, but not in such proportions. ${ }^{30}$

Similarly, the lower proportion of cups is due to the (almost) total lack of the C1 type, ${ }^{31}$ a characteristic and also easily identifiable autochtonous vessel form of the early Csőszhalom materials (those excluded, the proportion of cups in the Csőszhalom series falls back to $16 \%$ ). As the creation and use of the flowerpot-shaped vessels seems to be linked with specific customs or situations, ${ }^{32}$ their absence or presence is probably marking differences in local cognitive practice; perhaps this can be the case with $\mathrm{C} 1$ type cups (shape-shifting vessels) as well.
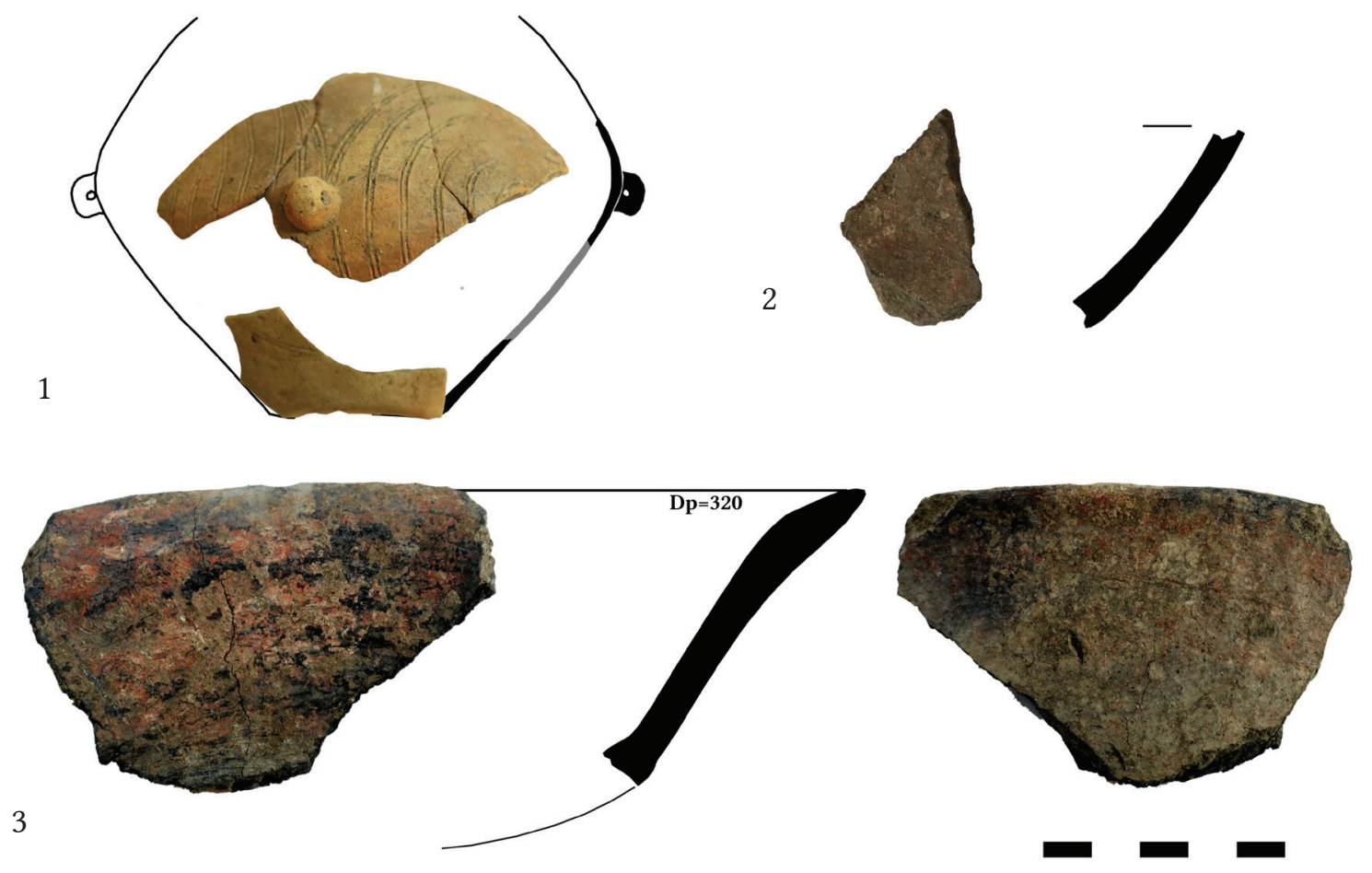

Fig. 8. Lengyel types in the ceramic record of Pusztataskony-Ledence 1. 1-2 - Feature 2-199.263, 3 - Feature 2-26. ID: 1 - 2010.4.199.150, 2 - 2010.4.199.180, 3 - 2010.4.026.117.

29190 altogether, 128 with the V2C2 column excluded. This column contains fragments where it was not possible to determine whether the fragment belongs to a V2 flowerpot or a C2 variant (fine, bomb-shaped cup). These pieces are usually small, undecorated rim fragments.

30 E.g. Kisköre-Gát: Kovács 2013, 57. t. 9, 58. t. 2, 59. t. 4; Szerencs-Taktaföldvár: Korek 1989, 17. t. 9.

31 For details see the description of the tar-coated vessels below.

32 SЕво̋K 2018a, 118. 

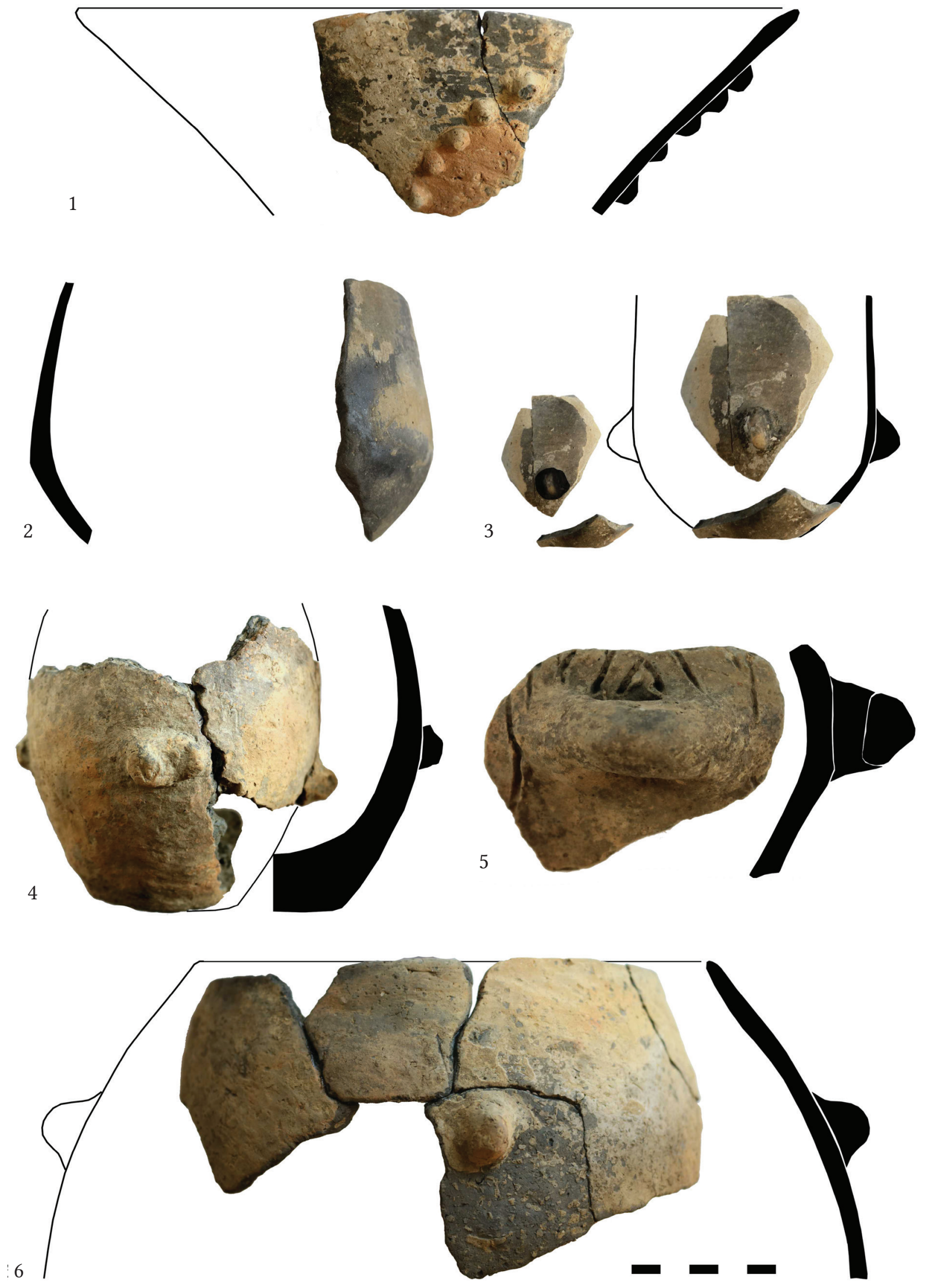

Fig. 9. Local/Tisza types in the ceramic record of Pusztataskony-Ledence 1. 1, 3, 5 - feature 2-25.25, 2, 4 - Feature 2-26.26, 6 - Feature 2-203.268. ID: 1 - 2010.4.025.277, 2 - 2010.4.026.026, 3 - 2010.4.025.004005, 008-009, 012, 4 - 2010.4.026.094, 105, 5 - 2010.4.025.085, 6 - 2010.4.203.001. 


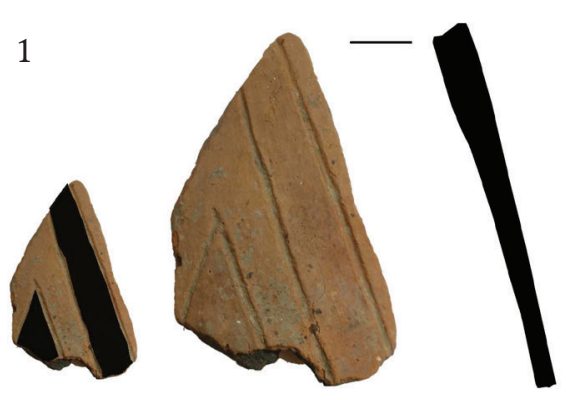

3
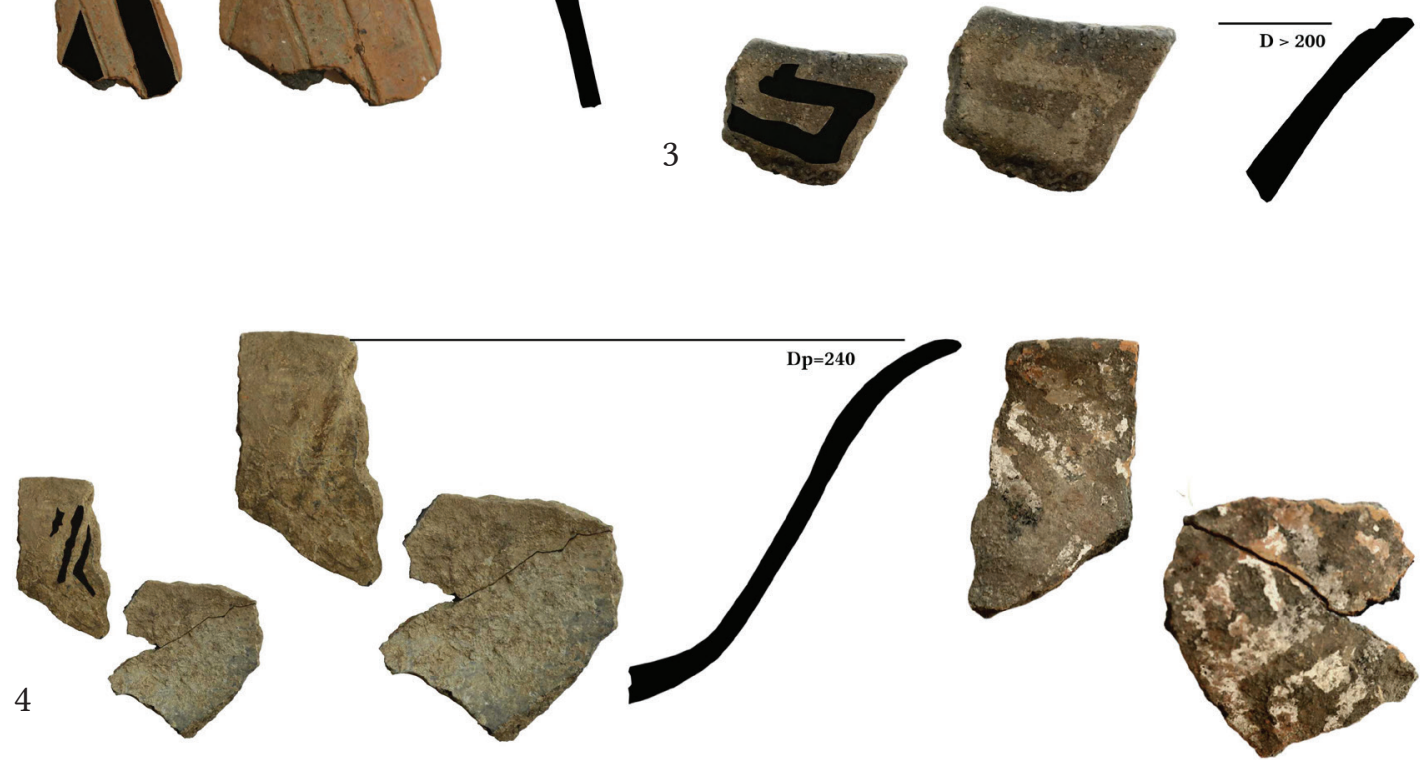

5
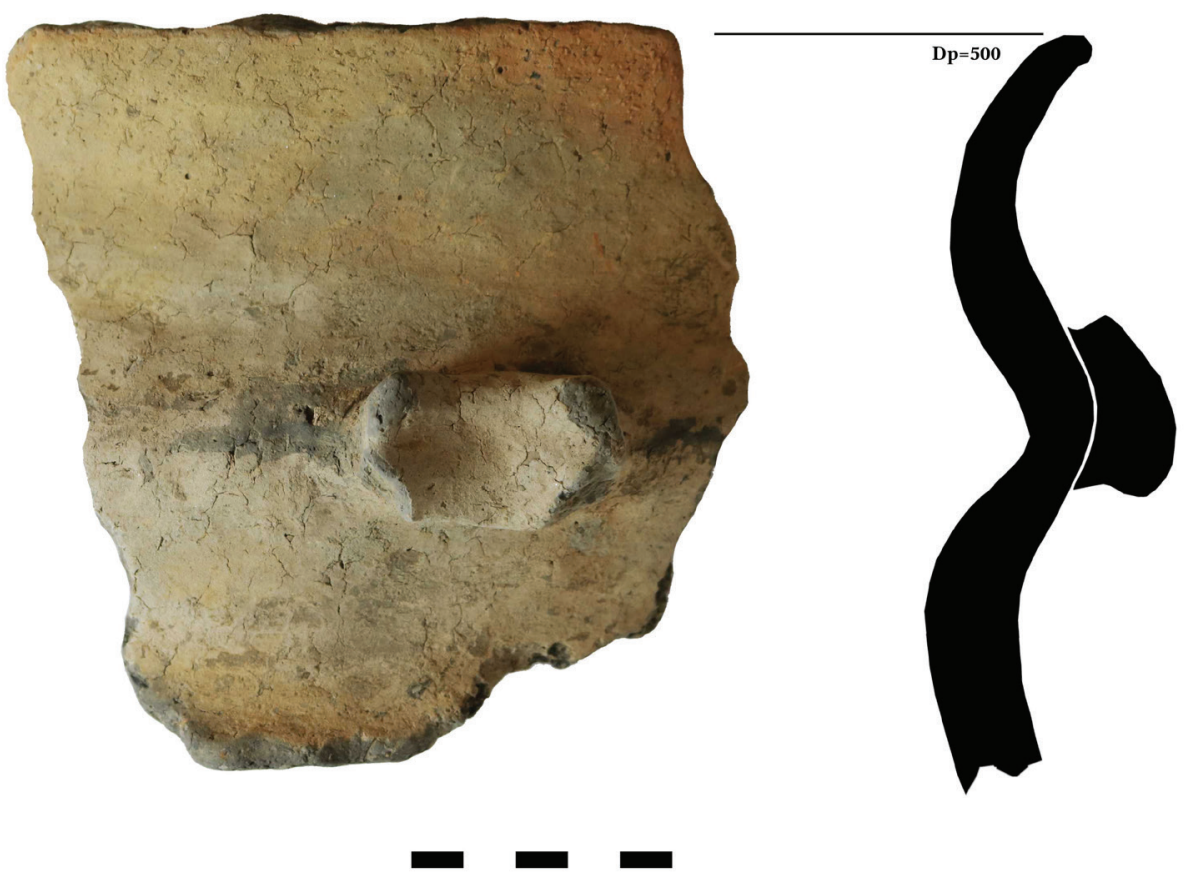

Fig. 10. Markers of a northern connection in the ceramic record of Pusztataskony-Ledence 1. 1-4 Feature 2-199.263, 5 - Feature 2-25.25. ID: 1 - 2010.04.199.159, 2 - 2010.4.199.166, 3 - 2010.4.199.646, 4 - 2010.4.199.152, 5 - 2010.4.025.404. 

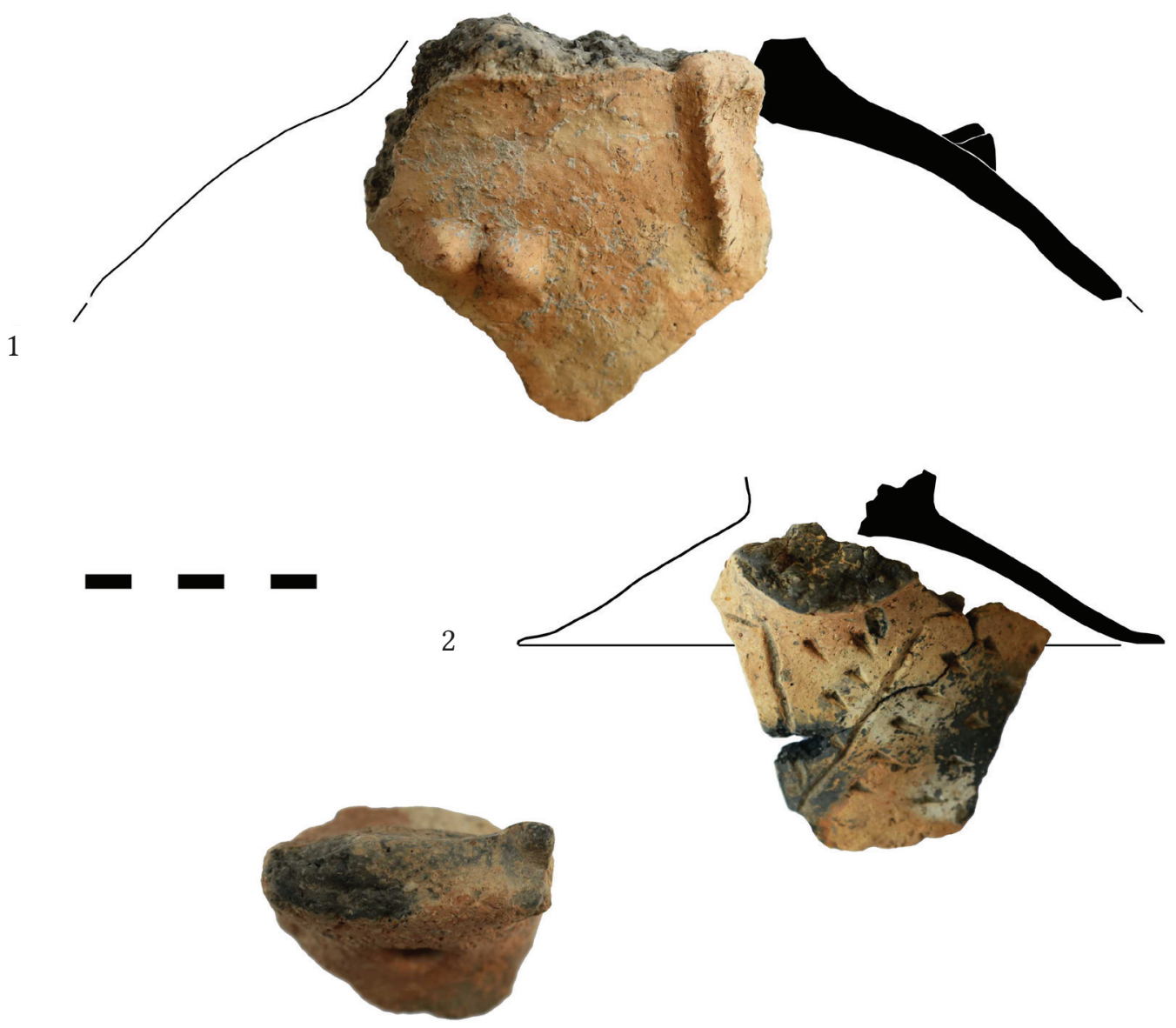

3
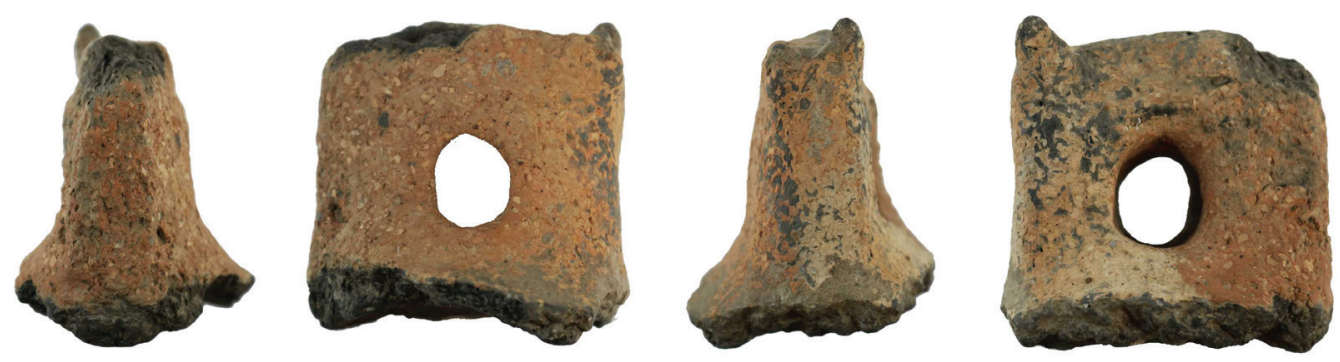

Fig. 11. Lids and lid-handles in the ceramic record of Pusztataskony-Ledence 1.1-2 - Feature 2-199.263, 3 - Feature 2-25.25. ID: 1 - 2010.04.199.153, 2 - 2010.4.199.188, 3 - 2010.4.025.385.

On the type level, marked differences pop up amongst the bowls, too. In every known site of the (northern) Tisza tradition, the leading type between fine bowls is that of the biconical bowls with a more or less carinated belly at the middle of their height, where the upper part is vertical or slightly in- or outward-inclining (T4 type). Simultaneously, biconical bowls with a low bellyline (around 1/3 of their body height) and outcurving upper walls (T3, T6 types) usually do not appear in coeval inventories of the Tisza tradition. ${ }^{33}$ These Lengyel-influenced forms, ${ }^{34}$ evolving perhaps in the ceramic record of some 'culturally mixed' northern settlements seem not to be present either in the inventories of coeval Tisza culture settlements or known culturally mixed settlements in the north, ${ }^{35}$ except for Polgár-Csőszhalom. ${ }^{36}$ The proportion of identified T3 type

33 E.g. Bodrogkeresztúr-Kutyasor: KovÁcs 2013, 18-22. táblák; Kisköre-Gát: KovÁcs 2013, 61. t.

34 SЕв̋̋K 2012, 102-103.

35 Based on L. Hajdú 2014; L. Hajdú 2015; KovÁcs 2013.

36 RАсZку - Sевőк 2014, Fig. 17.1-2; Sевőк 2007, 100, Fig. 1.14, 21. 
bowls in the study material (Fig. 7) seemingly exceeds the T4 types (21 vs 13 occurrences), but these numbers alone are false: there is a great number of typically base fragments (41) which may belong to either type. The fact that one cannot distinguish between fragments of the T3 and T4 bowl types based only on technology seems to underline previous results of thin section analyses by A. Kreiter, suggesting local production of foreign type vessels on the site. ${ }^{37}$

Other, typical Lengyel forms also appear in the material, even if rarely: fragments of altogether 6 tripartite vessels (LC3; Fig. 8.1), a straight-walled biconical cup type with sharp, low carination (LC8), and a variation of the T3 bowls with an even lower bellyline, strongly outcurving rim, and sharp carination (LT6; Fig. 8.2-3). The latter also has a less definite local variation (T6), which perhaps also count as a proof for local production of foreign types.

The rest of the local inventory matches the relevant types of Kisköre-Gát, and, to some extent, Csőszhalom as well. Not surprisingly there is a fair number of conical bowls (T1 type; Fig. 9.1), middle-sized or larger, relatively closed storing vessels (F5 and E variants; Fig. 9.4, 6), and large containers or bins (H type). A single example of the E4.2 type variant with a bulging 'Samborzec' neck (Fig. 10.5) underlines northern connections: its analogies appear rarely but regularly in the ceramic record of Polgár-Csőszhalom dűlö. ${ }^{38}$ Among jugs and jars only the more or less high-shouldered variants seem to be present (F2, F3, F4 type variants; Fig. 9.5), but not those with a low shoulder, oval, or egg-shaped body (F1), which appear in the ceramic record of Kisköre-Gát. ${ }^{39}$ As fragmentation effects the identifiability of these relatively large, plain vessels in a most negative way, their seeming lack can just as be a result of a too small sample set. The abundance of fine, bomb- or tulip-shaped cups (C2 type variants; Fig. 9.2-3) is similar to Csőszhalom and Kisköre. Their relatively high proportion again is a result of fragmentation distortion: as their material, being practically untempered, differs from the rest of the types in the inventory, even the smallest sherds can be identified with some certainty. Among the flowerpot type variants, there is a significant prevalence of the V2 group (flowerpots with a slightly curvy, round or rounded quadrangular base and outcurving rim). All four lid fragments recorded in the study material belong to the conical variant (L2; Fig. 11.2). Three of these are topped with a stylised animal, perhaps an auroch, for a lid-handle (Fig. 11.3), while the fourth one is probably an anthropomorphous, unique piece (Fig. 11.1).

\section{Type integrity analysis}

In a culturally heterogeneous situation like this it is very important to go one more level into detail and check, for each occurring type variant, type integrity as well. In the inventory compiled for the analysis type variants with almost the same physical characteristics, appearance, and type behaviour are gathered in in-between formations named type variant clusters, the introduction of which enabled us to utilize fragmentary information (as exact type variants can only be determined when there's at least a complete vessel profile at hand, which is rare). As our sample set, compared to the number of type variants involved, is way too small for a statistical analysis, it is also reasonable to focus on the type variant cluster level, and carry out further evaluation accordingly. 
Type integrity analysis pre-necessitates a clear knowledge of the determining characteristics of the given type as well as of the degree and ways of tolerable variation and deviation. As the ideal image of each type/type variant comprises information on expected shape, size range, technology to be applied, and decoration (including patterns and decoration technique), even a basic typological sorting is already part of such an investigation. But the data it can yield are incomplete and insufficient for interpretation without an analysis of decorations.

To understand why decorations are so important in this context, it is necessary first to learn about the production background of the pottery in the cultures under study. As a conclusion based on the results of previous researches, ${ }^{40}$ as well as current observations, it can be stated with some certainty that pottery production in both the Tisza and Lengyel communities is non-specialized (including occasional household-grade specialization), and low-tech. This is reflected by the firing marks of pottery and the overall lack of professional infrastructure (pottery kilns), the sometimes highly varying workmanship quality inside a type or type variant even among examples of fine types, the lack of large series of exact copies, and an abundance and diversity of decorations. ${ }^{41}$ Non-specialized production in the case of decorated vessels - especially when the patterns are complex - can also mean that instead of mere copying, the decoration process is a recreation and materialization of an unique, casual constellation selected from a set of related concepts and ideas, and shaped according to the maker's actual intentions. As such systems are usually delicate, a deviation in the material reflection tends to mark adjustments or changes in the cognitive realm.

Obviously, it is not implied that this process is necessarily present or can be identified by every decorated type of an inventory, but this is mainly due to the limitations of the archaeological method: beside requiring to find a community where pottery decoration is actually used to express cognitive content, the decoration itself must also be complex enough, its regulation strict enough, and its occurrence frequent enough to be detected.

According to our current knowledge, in the territory of the Tisza culture and the Northern Mountain Range the 'textile decoration' system and its painted derivations work this way, ${ }^{42}$ while among the Lengyel culture's vessel types probably tripartite vessels and painted biconical bowls (both flat-based and pedestalled variants) had such roles. ${ }^{43}$ Type integrity analysis is basically a very detailed typological analysis. This comprises, beside the description of occurring type variants, the mapping of their decoration with regard to vessel form (type variant), decoration technique, pattern structures, and motifs, preferably at the same time.

To begin with, a distribution diagram of decoration techniques in the sample set reveals basic trends (Fig. 12). About 40\% of the pattern occurrences is applied: knobs, bosses, or handles, while two-dimensional additions divide into three major categories: incised, black, and red painted. Of these, incised pattern variants give the overwhelming majority (89.4\%) of 2D patterns, and the rest is divided between black and red painting, with a slight prevalence to the former. In all cases, the abundance of variants is quite surprising.

40 Kreiter et al. 2009, 114-115; Kreiter et al. 2017, 13.

41 SЕво̋к 2018, 112.

42 SeвőK et al. 2013, 56-57; RACZKy - FüZESI 2018, 152; SEвőк 2018a, 117-122.

43 Sikıósi 2013, 102 (only for tripartite vessels in funerary context); ZALAI-GAÁL 2010, 75-76. 


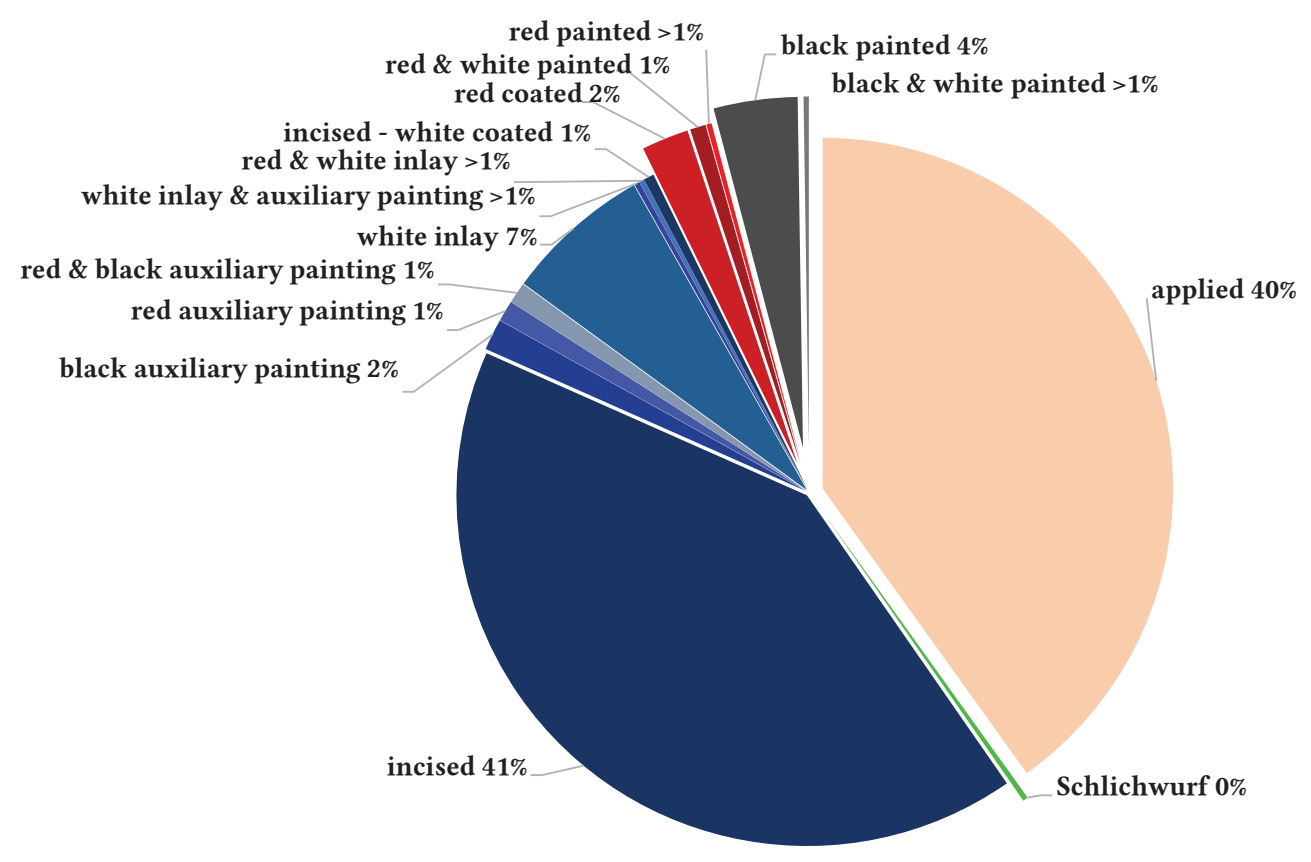

Fig. 12. Distribution of decorations by technique.

As for applications, altogether 400 occurrences were recorded in our database (Fig. 13). These include knobs and bosses, rows of small knobs forming linear patterns, as well as large grip-handles, and handles. Regrettably, the majority of occurrences cannot be linked even with type groups, but there is an overall prevalence of the size range group 3, suggesting a connection between large vessels (jars with no handle, containers) and appliqué decoration. Another peak can be seen for smaller, round and oval knobs in the C2 group, i.e., tulip- or bomb-shaped, fine cups. Jugs and jars only have an occasional knob, mostly by the foot of the neck, but the type variants of the F1-F4 clusters are two-handled. The single recorded bin fragment with a trace of application has only the place of a large boss or grip handle. As for bowls, round or oval knobs, placed on the carination or bellyline are common additions with every type variant clusters. In the cases of almost all recorded examples of flowerpots, and some of the $\mathrm{C} 2$ cups, knobs were part of a combined decoration, appearing together with an incised pattern variation. This distribution matches local traditions in general, as analogies can be found in every coeval settlement's ceramic inventory on the Great Hungarian Plain as well as in the Upper Tisza Region. The only notable exception is a downward-pointing, oval knob (code 122) appearing on the carination/bellyline of an unidentifiable vessel and a T3 type bowl, which, together with the form's type variant, has its origins in the Lengyel ceramic tradition. ${ }^{44}$

The relation of two-dimensional patterns and ceramic traditions is somewhat more complex, only to be revealed by a combined mapping of shape, technique, and motifs (Fig. 14). The study material contains altogether 18 black painted pieces, which can be rendered into three categories. Of these, black pattern painting is the most prevalent with 15 occurrences, of which the pattern can be identified in 10 cases (Fig. 7.3; Fig. 10.2). Black painting may exhibit two related traditions. It seems to appear first in inventories of the earliest Tisza culture in its central and southern distribution area (e.g. Öcsöd-Kováshalom ${ }^{45}$ Szegvár- 


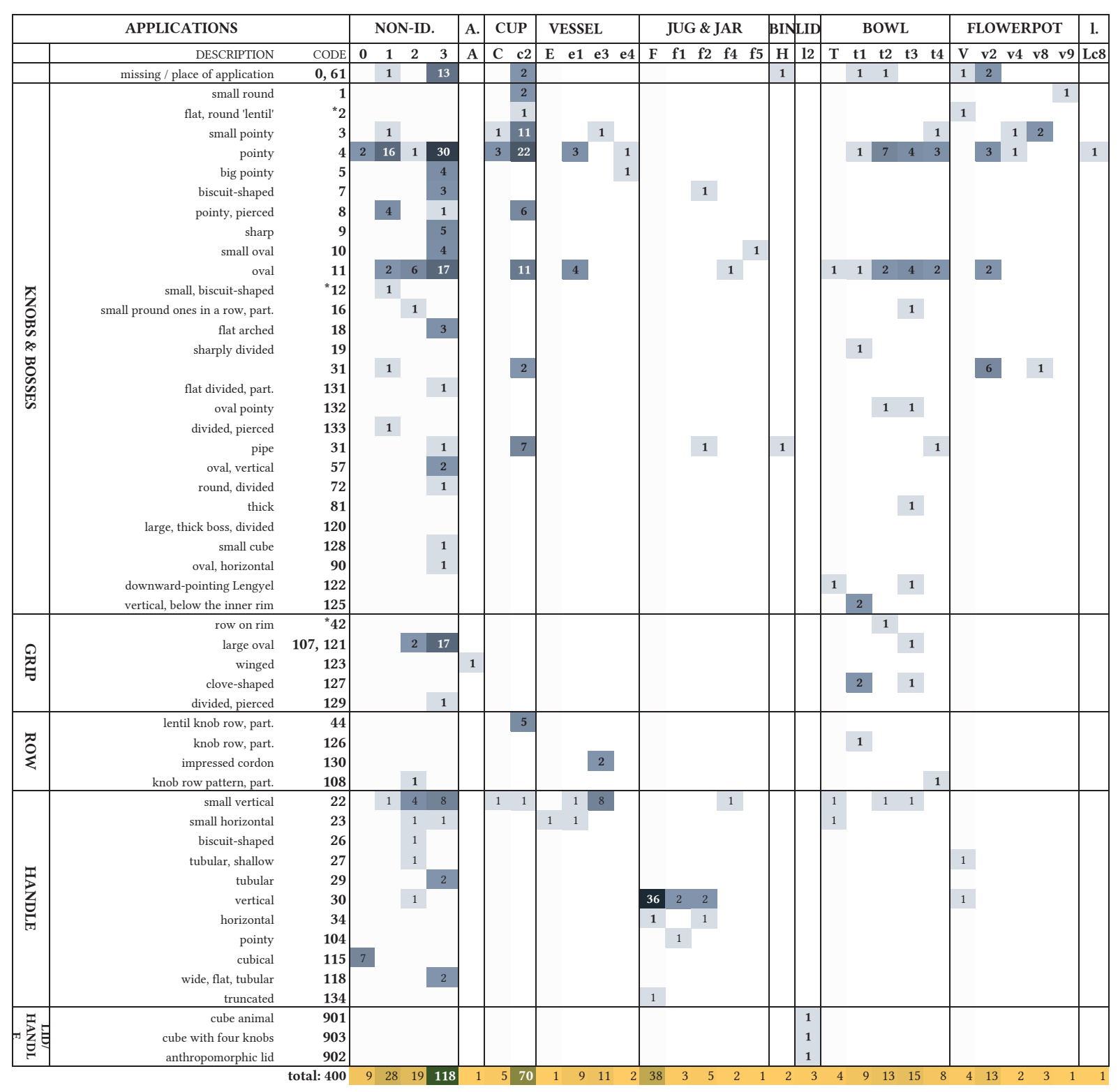

Fig. 13. Distribution map of applied decorations by shape and backing vessel type.

Tüzköves, ${ }^{46}$ Hódmezővásárhely-Gorzsa, ${ }^{47}$ Békés-Povád ${ }^{48}$ ), upon which another, much more decorative variant emerges, appearing in inventories of 'culturally mixed' settlements in Northeast Hungary (e.g. Aszód-Papi-földek, ${ }^{49}$ Polgár-Csőszhalom-dűlő, ${ }^{50}$ Tiszatardos-Csobaji út mentén $\left.{ }^{51}\right)$. Despite the same technique the pattern set as well as the set of backing types of the two styles differs greatly. While the southern variation only uses loosely-contexted, unique patterns, cross- and linear motifs, sometimes dot clouds on larger vessels, the northern one also comprises - and prefers - dense runaround zigzag- and deltoid grid variants, as well as distorted motifs adapted from the Tisza culture's 'textile' decoration. The backing

46 KoReK 1987, Fig. 22.

47 HoRváth 2005, 10. kép 1.

48 Trogmayer 1962, 14. t. 3, 7, 10.

49 Kalicz 2008, Abb. 13-15.

50 RAсZкy et al. 2007, Fig. 8.5-6; Sевőк 2007, 109-111, Fig. 6.1-7, 9, Fig. 7.1-4.

51 L. HAJDÚ 2015, 88 with further examples. 
Basic connections and stylistic affiliations of the Late Neolithic settlement...
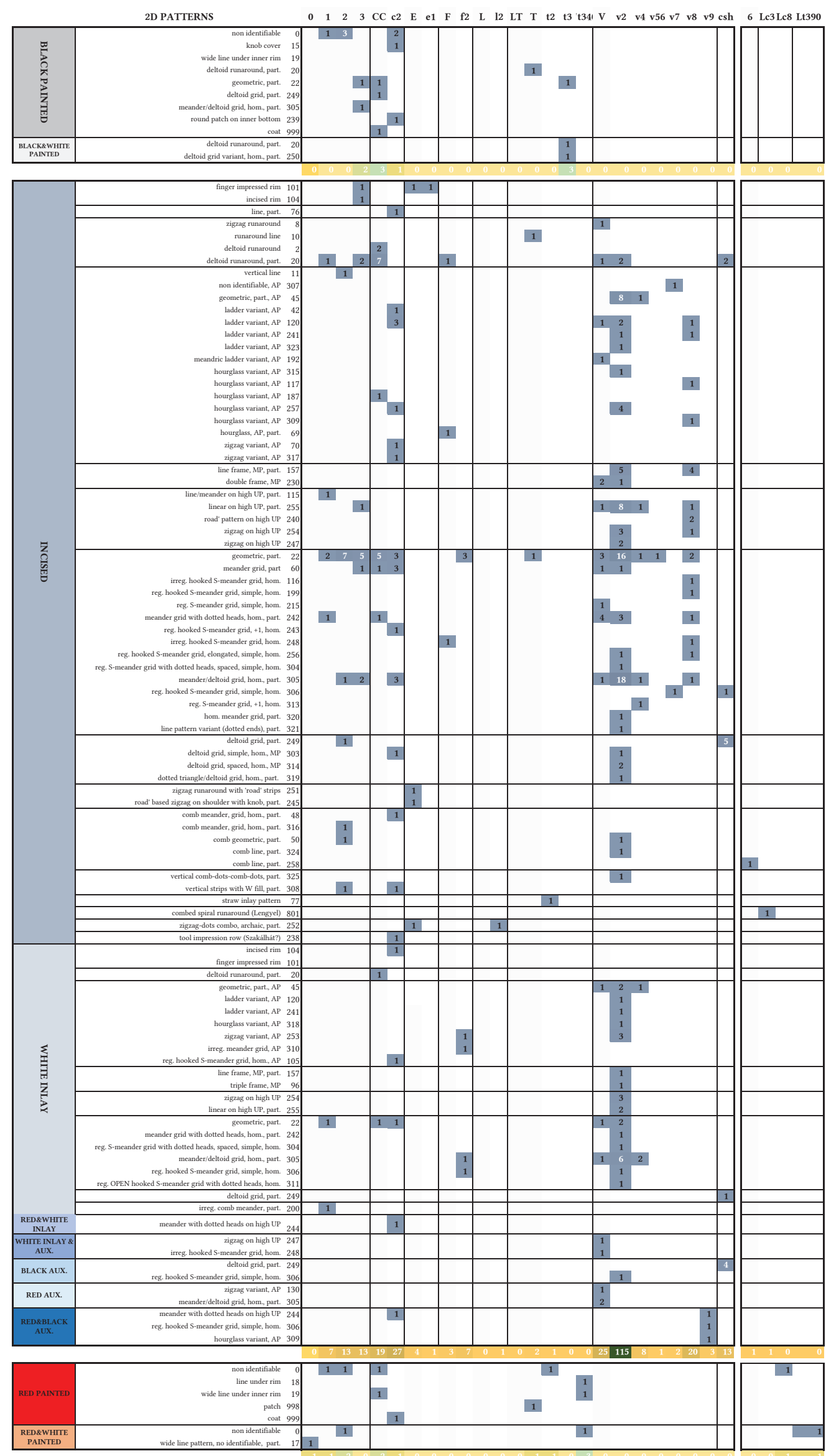

Fig. 14. Distribution map of two-dimensional decorations by shape and backing vessel type. 
types include simple cups, conical, and biconical bowls, as well as two-handled jugs and jars. The occurrences in our sample set seem to link rather with this latter stylistic variant: the identified backing vessels are exclusively cups and bowls (although the two fragments in the 3 size range category might belong to jugs or jars), and the patterns are zigzag-, deltoid- or meander runarounds or grids. These patterns recur on a T3 bowl fragment, but the technique is a bit diverse: here the black pattern is painted on a creamy white slip base (Fig. 10.4). The only currently known analogy for this piece was found in House 11 in the lowermost layer of the Polgár-Csőszhalom tell. ${ }^{22} \mathrm{~A}$ small cup fragment coated in

1
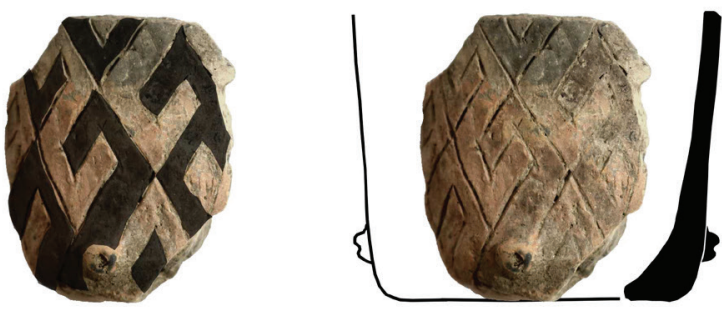

2
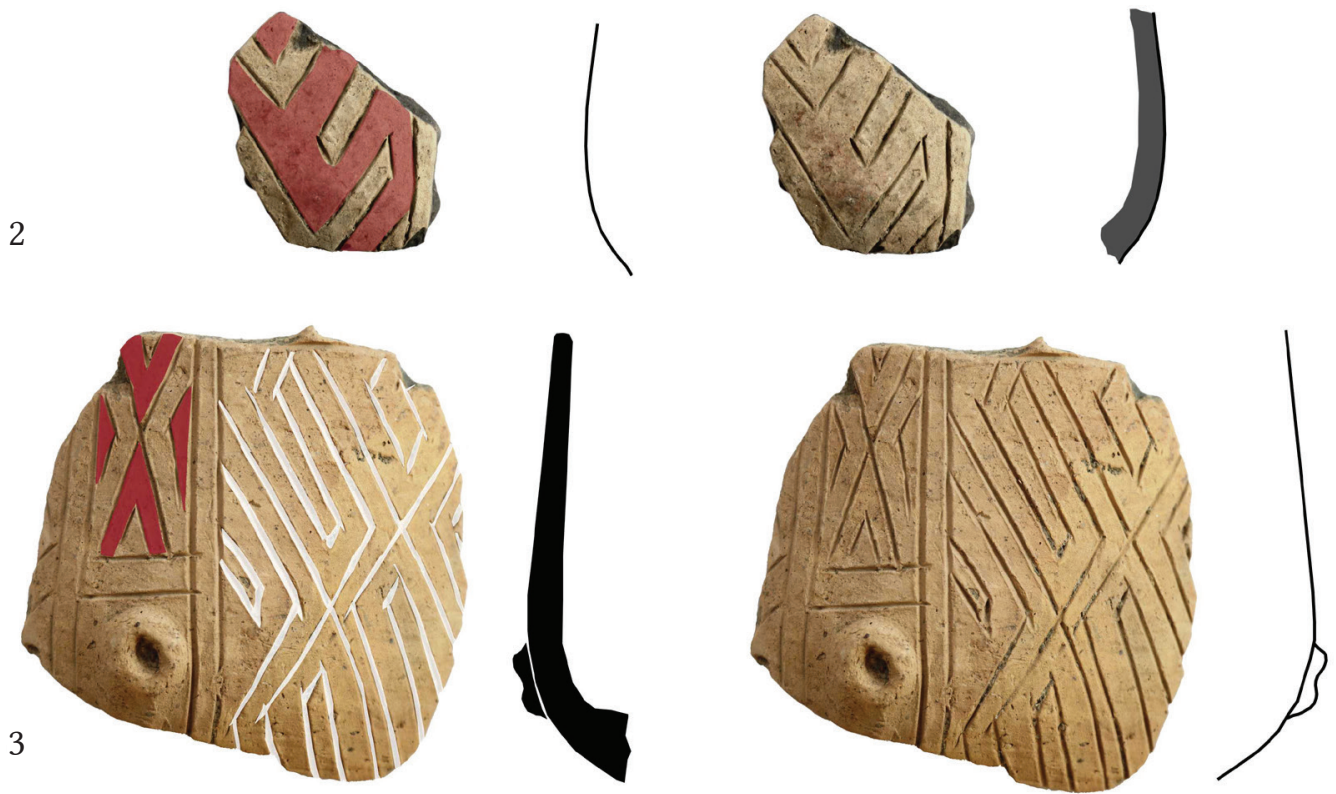

4
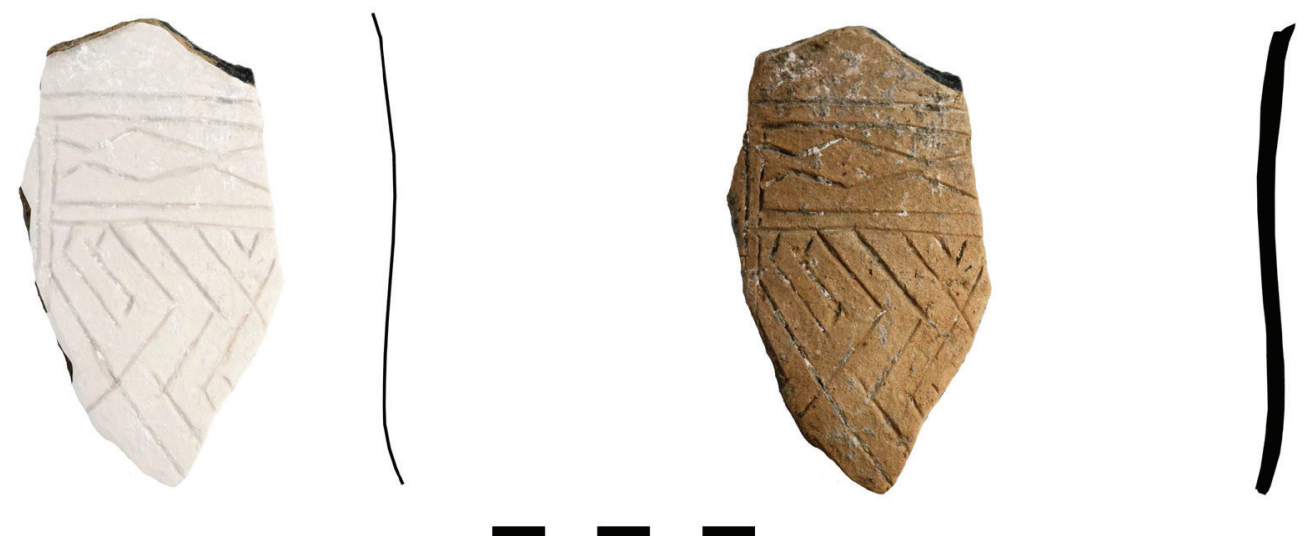

Fig. 15. Flowerpots in the ceramic record of Pusztataskony-Ledence 1. 1, 3 - Feature 2-199.263, 2, 4 Feature 2-25.25. ID: 1 - 2010.04.199.636, 2 - 2010.4.025.459, 3 - 2010.4.199.618, 4 - 2010.40025.458. 
1
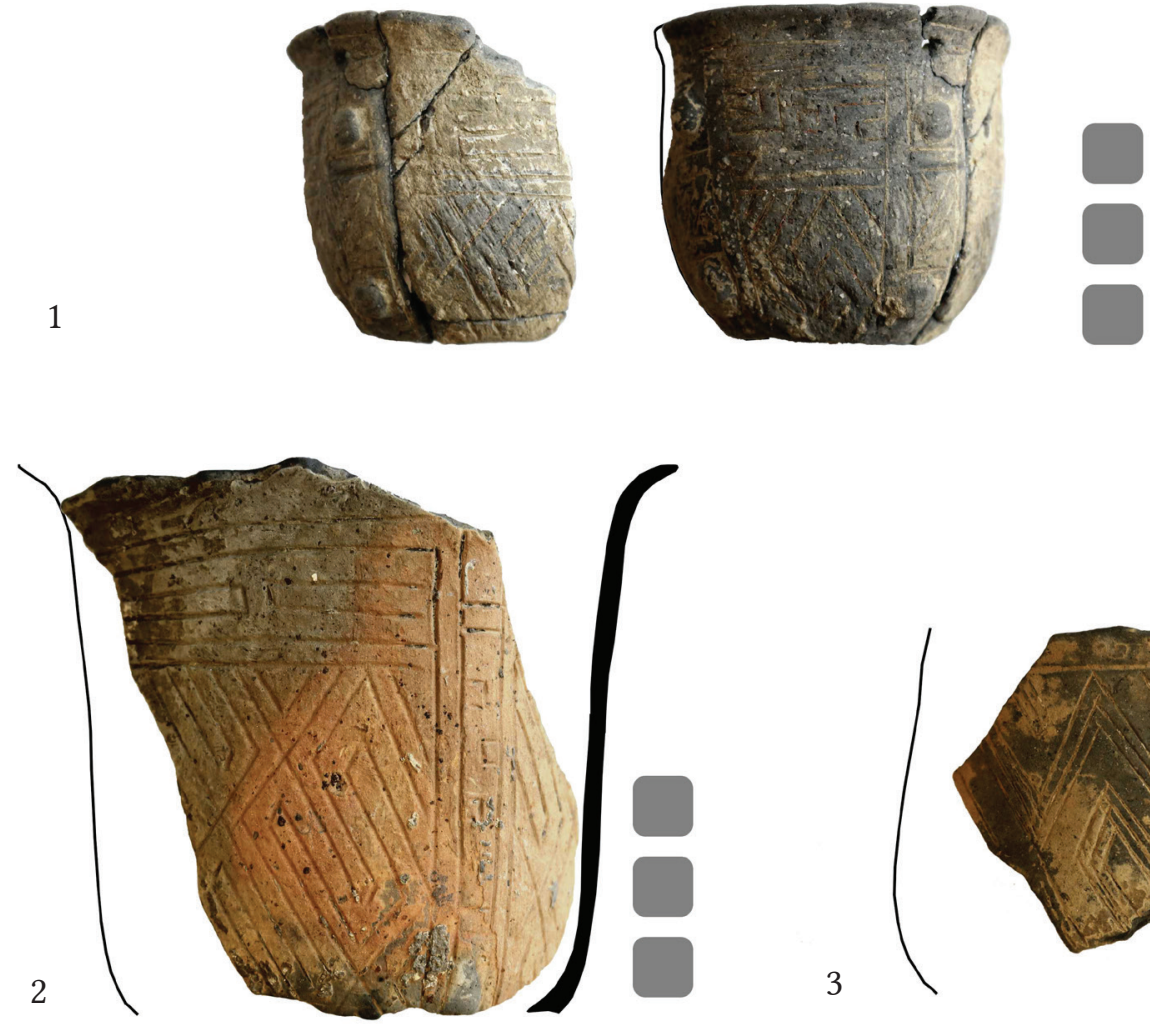

3
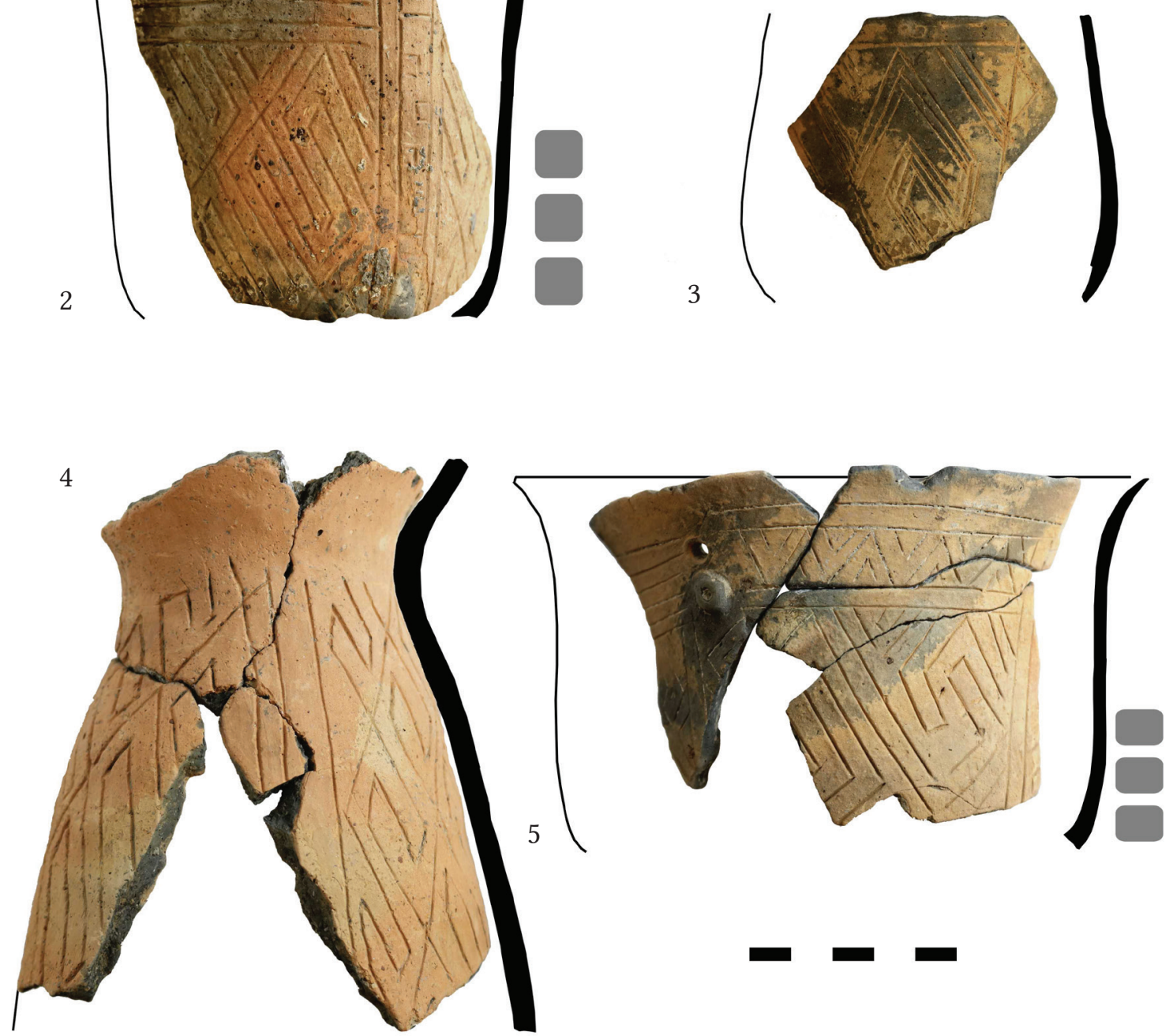

Fig. 16. Vessels with incised decoration in the ceramic record of Pusztataskony-Ledence 1. 1-3 - Feature 2-25.25, 4 - Feature 2-26.26, 5 - Feature 2-199.263. ID: 1 - 2010.04.025.462, 2 - 2010.4.025.017-018, 3 - 2010.4.025.049, 4 - 2010.4.026.002, 5 - 2010.4.199.624.

black tar (Fig. 7.2) might emphasize this connection. Tar-coated cups (C1 type, cross section shifting vessels), with or without a straw inlay pattern decoration are a characteristic autochtonous type in the approximately coeval horizontal settlement of Polgár-Csőszhalom ${ }^{53}$ 
as well as in some 'culturally mixed' settlements in the north. ${ }^{54}$ However, fine, C2 or C3 cup variants with similar coating and patterns sometimes appear in the record of the earliest Tisza horizon of settlements (e.g. Battonya-Gödrösök ${ }^{55}$ Ócsöd-Kováshalom ${ }^{56}$ ) in the south, as well as in Kisköre-Gát. ${ }^{57}$ Despite that the sherd in the study material is too small to the vessel to be rendered into any typological category, the finish of the outer side - roughing by rubbing coarse grog in the semidry surface - allows us to affiliate it with the northern, Csőszhalom-type cross section shifting vessels, of which this technique is an exclusive characteristic among Late Neolithic ceramic types. ${ }^{58}$

The technique itself, just like black pattern painting, is rooting in local Middle Neolithic traditions. ${ }^{59}$ The northern variations of the two stylistic ways relate differently to the original versions: while the tar-coated straw inlay style undergoes a major transformation effecting both the backing types and the pattern set, in the case of black pattern painting the alteration is a mere completion of the already existing set with new types and motifs.

Incised decoration is frequently and diversely completed by various kinds of auxiliary colouring. The vast majority of the identified backing types is ('textile' decorated) flowerpot variants (187 motif occurrences), cups (28 occurrences), and in one case a two-handled jar (Fig. 9.5). The exact technique itself does not seem to be decisive regarding affiliation to a region or a ceramic tradition. Red or white inlay may appear in inventories anywhere in the Tisza culture's inhabitation area, though the technique seems to be less frequently used in settlements in the north (Fig. 15.3). ${ }^{60}$ Black auxiliary painting (Fig. 15.1) also appears occasionally on 'textile' decorated vessels (exclusively flowerpots) in Polgár-Csőszhalom, where, rarely, infirm incision and black painting with dense runaround patterns also appear together on high pedestals of bowls (Fig. 10.1). ${ }^{61}$ A black-and-red auxiliary painted flowerpot fragment is known from the nearby Kisköre-Gát, ${ }^{62}$ and another from Tiszakeszi-Szódadomb ${ }^{63}$ but there's not enough data to interpret these connections. The technique itself resembles the tar-coated and red painted vessels of the Szakálhát and early Tisza cultures. ${ }^{64}$ Red auxiliary painting (Fig. 15.2) is perhaps an occasional variation of the common red-and-white, examples of which may occasionally occur in any approximately coeval settlement of the culture. ${ }^{65}$ The two incised fragments with a white coating (Fig. 15.4) are somewhat unique, and much more interesting. This technique is completely unparalleled outside the settlement; here, a complete example was unearthed in one of the Late Neolithic burials. That vessel, also a flowerpot with an originally incised decoration completed by red and black auxiliary painting, was thoroughly coated in white at

54 E.g. Szerencs-Taktaföldvár, Ináncs-Dombrét, Gönc-Kenderföldek (L. HAJDú 2015, 89).

55 Goldman 1981, 8. kép 1-8, 9. kép 1-8, 10. kép 1-10.

56 RACZKY 1987, 76, Figs 8-9.

57 Korek 1973a, 48. t. 5; Kovács 2013, 56. t. 1-6.

58 RACZKY - SЕво̋K 2014, 81.

59 Goldman 1981, 37-39.

60 This phenomenon may be caused by a bias of research: as tell settlements are much more intensively researched, their sample sets are many times larger compared to the northern area.

61 RAсZку - Sево̋к 2014, 78, Fig. 15.3.

62 Author's research, unpublished.

63 Kovács 2013, 87. t. 6.

64 Goldman 1981, 79; Raczky 1987, Figs 8, 9.

65 E.g. Bodrogkeresztúr-Kutyasor (KovÁcs 2013, 17. t. 6, 8-9); Kenézlő-Báji-homok (Kovács 2013, 28. t. 1); Kisköre-Gát (KovÁcs 2013, 57. t. 1). 
some point of its life. ${ }^{66} \mathrm{~A}$. Anders and P. Raczky supposed, based on an analogy from a similar context, that the reshaping of the object had happened in connection with the funerary process; ${ }^{67}$ but the appearance of similar vessel fragments undergoing a similar transformation in an everyday, household context seems to question this interpretation.

All technological variations of the 'textile'-decorated vessels in the study material seem to share the same set of patterns and structure variations.$^{68}$ Little can be said on the latter based on such a relatively small and fragmented sample set: fourfold division seems to be preferred to twofold, the main panels are always undivided, and the upper closing bands wide, but stretching only above the main panels (Fig. 16.1-5). The main panels (MP) are filled with a homogenous pattern, mainly a closed simple or hooked S-meander grid, less frequently a deltoid grid, and in one case an open, hooked S-meander grid. Auxiliary panels (AP) are decorated with hourglass-, ladder- or zigzag variants, while upper panels (UP) are filled with linear or zigzag motifs. This composition fits the basic style variant appearing in the northern part of the culture, and matches almost perfectly to the local style variant of Kisköre-Gát.

There is a variant among the meandric grid patterns where the basic motif's strip is divided into three or four, creating a 'combed' effect (Fig. 16.3). These patterns seem also to be connected with the 'textile' decoration based on the distribution of their backing types (the panel frame was only obtained in a few cases), representing a well separable part of the related pattern set. Currently there is only one known settlement, Aszód-Papi-földek, where this variation appears in numbers; ${ }^{69}$ a few such sherds were also identified in the ceramic records of Polgár-Csőszhalom ${ }^{70}$ and Kenézlö-Báji-homok. ${ }^{71}$ Without suggesting a connection (but raising its possibility) it must be mentioned that 'combed'-line meanders as well as runaround spirals represent pattern variants characteristic of tripartite vessels of the Lengyel tradition ${ }^{72}$ - an example of which was just identified in our study material. ${ }^{73}$

An archaic element of the ceramic inventory, in its stylistic context totally unrelated to the previously discussed ones, is exhibited by the E vessel type group (Fig. 9.4, 6). These slightly biconical or rounded, middle-size or somewhat larger, handleless container- or cooking vessels are usually undecorated except for a double row of knobs ordered in a zigzag pattern, running around the upper part of their body; but sometimes the knobs are connected by dashed strips (='road' motif). Dashed strips are also used separately, as e.g. horizontal rows under the rim. They appear in late Szakálhát context as well as in early Tisza materials. ${ }^{74}$

The evaluation of painted examples is, as usually, way more problematic not only because of the very small number of occurrences (altogether 14 in the study material) due to the minor role they seem to play in coeval Late Neolithic inventories in the area, but also as a consequence of the extreme vulnerability of painted surfaces: even the recorded pieces are mostly

66 ANDERS - RACZKY 2014, 195, Fig. 3.

67 ANDERS - RACZKY 2014, 197-199.

68 For a detailed description of basic structure and variants see SЕво̋ 2018а.

69 KALicz 1985, 61-63. képek.

70 Raczky et al. 2003, Fig. 6.6, Fig. 7.4.

71 Kovács 2013, 31. t. 3, 5.

72 Kalicz 1985, 48. kép 2, 4-5, 7-10, 12, 60. kép 1-14.

73 A slightly different variation of 'combed' or 'band'-meanders was preferred by the community of Hódmezővásárhely-Kökénydomb (BANNER 1940, 71. t. 11-12, 16, 74. t. 1, 5,7. t. 2, 20, 23, 25-27).

74 E.g. Hódmezővásárhely-Kökénydomb: BAnner 1940, 64. t. 1, 4, 7, 8; Szegvár-Tüzköves: KoreK 1987, Fig. 3. 
unidentifiably worn. The remaining information suggests the joint presence of two styles or ceramic traditions with painting. Red coating on and especially inside cups may have its roots in the local, post-Linear Pottery tradition, while red as well as red-and-white pattern painting, mainly on T3 type biconical bowls, seems to link with the coeval early Lengyel style. The presence of this latter tradition was proven earlier by an analysis of burial 1-718, containing a painted early Lengyel type bowl. ${ }^{75}$ Besides, fragments of at least one similar bowl (Lt390) with red-and-white painting, as well as of a biconical cup (Lc8) with red painting were identified in the current sample set.

\section{Conclusions of the pottery analysis}

To give an appropriate interpretation of the situation it is necessary to understand the structure of the ceramic traditions and their inventories involved, as well as the possible roles of the types in each of them. Both major cultural units participating in this interaction emerged directly from Linear Pottery groups, and, as a result, their inventories share a basic composition and characteristics as well as a common technological and probably fundamental production background, all rooting in the socio-cultural and stylistic traditions of the Linear Pottery complex. The ceramic inventories of the Lengyel and Tisza cultures (together with the 'culturally mixed' northern, Csőszhalom-type variation) basically consist of three large type clusters (or four, including miniature vessels, which, however, cannot be interpreted as obviously regular types in a household's inventory). The first cluster, embracing the overwhelming majority of the ceramic finds and including a wide range of vessel forms, is that of the probably primarily or exclusively utilitarian ceramics. The vessels in this group may be smaller, middle-sized or larger, of medium or good quality. Excellent finish (polish or varnish) may appear only on smaller liquid containers like less closed cups and bowls. The applied decorations are simple, scarce, moderate and basically functional like knobs, knob-handles, handles, bosses, or applied cordons to enhance grip, finger impressions, or mainly rough barbotine decorations to raise surface. This basic set is completed by a small cluster of vessel forms incorporating only a few types (flat-based and pedestalled bowls, fine cups, small, fine vessels) which are usually small, less frequently medium-sized, of good or excellent quality, and completed by a more or less elaborate decoration (representative or 'tableware', including signature types). The third group is that of the large, immobile or builtin containers (or bins). Their quality and design varies greatly by culture, but as a rule they are always more or less decorated. From the symbolic communication's point of view, there is a big difference between the three groups,$^{76}$ and this difference is well reflected by the diverse tempos of evolution of their types throughout the Middle and Late Neolithic. In everyday context, the bulk of symbolic communication seems to get realized via the few signature types.

A survey through the results of the typological and stylistic analyses reveals a picture that is very similar to the pattern of interaction as reflected by the ceramic record of the early phases of Polgár-Csőszhalom, even if the current situation is considerably simpler. In terms of ceramic style the 'utilitarian' vessels and containers all reflect the local early classical Tisza tradition; the signature types include flowerpots, and - partially - C2 cups. The presence of other styles or traditions is restricted solely to the appearance of some of their signature types: black painted, pedestalled bowls with a deltoid runaround pattern, perhaps a tar-coated cup, and a vessel with Samborzec neck marking some influence of the northern, culturally 
mixed zone, and red painted biconical bowls, biconical cups and tripartite vessels originating in the Lengyel tradition. The appearance of a single open meander grid variant can point in multiple directions. Open meanders only appear in the material of some settlements in the southern inhabitation area of the Tisza culture (e.g. Szegvár-Túzköves), but they also appear in Aszód-Papi-földek.

As far as one can tell from such a small sample, all these complex types seem to be present undegraded, and there is currently no trace of new, hybrid types bearing characteristics of two or more of them, suggesting, that, despite the challenging cognitive environment in which they had been created, the concepts and ideas behind each type remained at least relatively intact. The presence of the type variants of Lengyel origin thus might mark the introduction of new customs, activities, or contents in the life of the local Tisza community, probably as a result of the arrival of new members with Lengyel identity, which, at least for some time, persisted in a fundamentally unchanged form side by side with the practices of the locals. Based only on this relatively small ceramic set little is to be said about the spatial origin of the Lengyel influence: other stylistic connections point northward, and, furthermore, the strong presence of bowl variants with low carination and outcurving upper part suggests contact with communities amalgamating Lengyel stylistic elements in that area.

\section{Lithic analysis}

The archaeological record of the Late Neolithic settlement of Pusztataskony-Ledence is scarce in lithics, especially compared to Polgár-Csőszhalom or Aszód. As a consequence, the sample set yielded by the southernmost building cluster with only 12 pieces altogether was not suitable for a statistical analysis, requiring an extension of the study area. As the processing of the material of the southern settlement part (originally Pusztataskony-Ledence 2) was in an advanced state, this unit, incorporating the southernmost house cluster as well, was chosen for the topic of the current analysis.

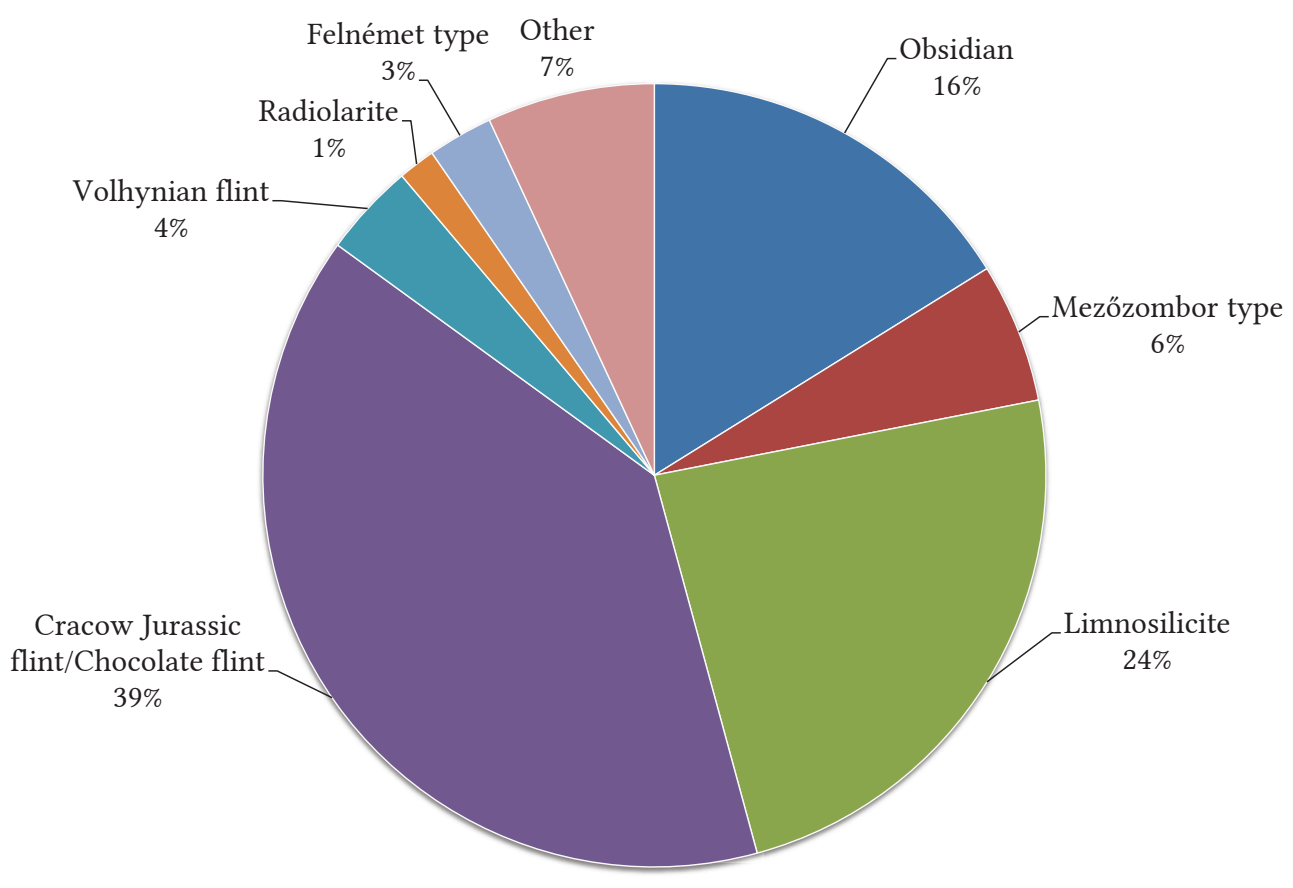

Fig. 17. Distribution of raw materials in the lithic record of Pusztataskony-Ledence, part site 2. 
Altogether 260 chipped pieces came to light from clear Late Neolithic contexts from features in the original Pusztataskony-Ledence 2 settlement part. The most frequent raw materials arrived here from a northern direction, from a distance of 350-450 km (Fig. 17). These pieces can be identified either as chocolate flint from the Holy Cross Mountains or in some cases as Cracow Jurassic flint; their sum adds up to $39 \%$ of the lithic record. The second largest group by raw material (24\%) consists of several different limnosilicite types from the North Hungarian Range. The majority of these pieces originates in the Tokaj Mountains, located at a distance of $90-100 \mathrm{~km}$. A specific variation, the Mezőzombor type, can be easily identified by its greyish-bluish silky colour and banded texture, so it was handled separately from the rest: pieces of this type add up to $6 \%$ of the whole assemblage. Obsidian also arrived from the same region: $16 \%$ of the chipped pieces were made of it. In most cases, obsidian finds can be categorized as Carpathian 1 subtype according to cortex and translucency. Another diagnostic northern flint variant is the Volhynian flint from Western Ukraine at a distance of 400-450 km, giving $4 \%$ of the sample set. Beside these, a minor part of the lithic record consists of radiolarites from the Klippen Belt in the Carpathian Mountains without any other specific character (1\%), as well as silicified sandstone, i.e., Felnémet type from Egerbakta in the western part of the Bükk Mountains (3\%), while a small part of about $7 \%$ comprises examples made of other undiagnostic flint types of unknown origin.

A comparison of the different raw materials by main technological categories reveals an overall lack of raw nodules or blocks in the assemblage, which places the initial phases of the knapping activity rather off-site (Fig. 18). It seems that cores were similarly infrequent in the settlement; they appear in the greatest number among different types of limnosilicites with both corticated and uncorticated variants. Corticated cores made of Cracow Jurassic flint/chocolate flint and obsidian are also present, but only in minor quantities. Moreover, uncorticated obsidian cores are missing, which is rather the consequence of the natural, small pebble form of this material. The high ratio of obsidian corticated debitage products can also be explained with this characteristic. Such debitage products are frequent among the Volhynian flint too, but the uncorticated pieces are in general more abundant in every group. The rest of the raw materials like radiolarite, Felnémet-type, and other undiagnostic pieces are not representative enough to envisage the whole chaîne opératoire on the settlement.

To sum up the first results, Cracow Jurassic flint/chocolate flint, different types of limnosilicites and obsidian formed the basis of a moderate, though focused knapping activity at the southern part of Pusztataskony-Ledence. From a technological point of view, obsidian seems to be a little bit different, but this could be an effect of the starting form of this material. This supposition is strengthened by a yet unpublished evaluation of the lithic record of Polgár-Csőszhalom, in the course of which similar differences were observed.

A detailed technological and typological analysis is still pending, not to mention the complete evaluation of the whole settlement, so this short report is dedicated only to the raw material distribution and the observation of the main technological groups. Considering the internal distribution of the material on this part of the site, it is interesting that among the archaeological features only two pit complexes contained 75 percent of the whole assemblage, which suggests a very concentrated activity at the settlement. 


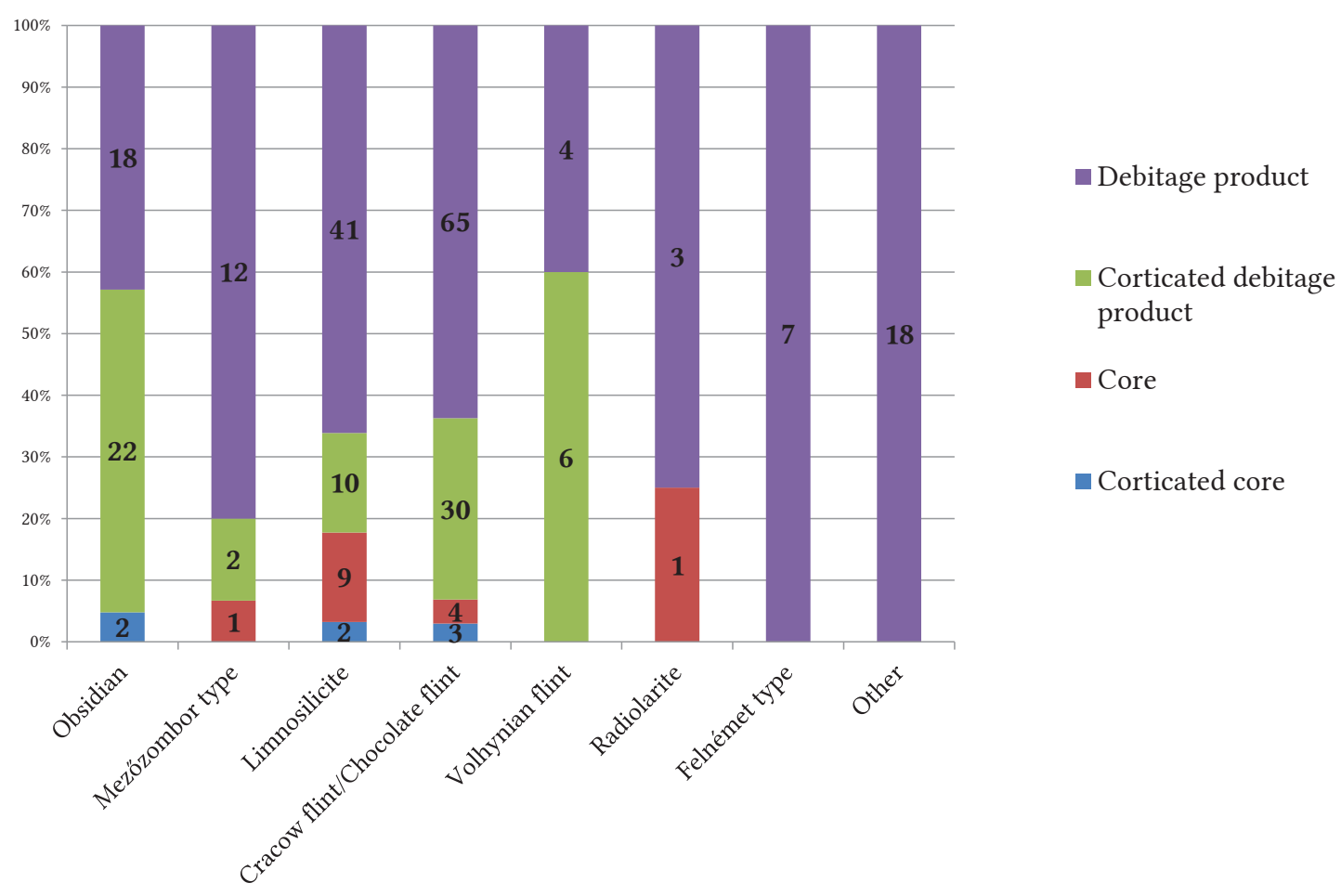

Fig. 18. The distribution of main technological groups by raw material in the lithic record of Pusztataskony-Ledence, subsite 2.

It is hard to find coeval sites for comparison, however necessary that would be for interpretation. As of the lithic material of Kisköre-Gát, little was published, ${ }^{77}$ and the two pieces analysed in more detail by E. Bácskay can be linked with the classical Alföld Linear Pottery settlement on the site rather than the Tisza horizon. The situation at Aszód is different: as it is one of the best studied chipped stone assemblages in the Hungarian Neolithic, it became a reference for any comparative raw material analysis. ${ }^{78}$ Its assemblage is distributed among Transdanubian, North Hungarian, and Transcarpathian (long-distance) sources, but the most frequent materials are obsidian and limnosilicites.

To put our results in a wider context it is worth to mention some further, already published information from this region and timeframe. According to M. Kaczanowska, there is, in general, a significant drop in the obsidian ratio in assemblages from the Great Hungarian Plain during the corresponding, so-called second chronological horizon, i.e., the Late Neolithic. ${ }^{79}$ Simultaneously, different types of limnosilicites from the North Hungarian Range, together with increasing amounts of long-distance raw materials especially from Lesser Poland and Western Ukraine add up to the picture. This trend was also highlighted by K. T. Biró, who, besides this phenomenon, also connected the growing intensity of the settlements with the increasing size of assemblages during the Late Neolithic. ${ }^{80}$ It seems that among the distant sources - apart from the Cracow Jurassic flint, which is already apparent during the lifetime of the former Alföld Linear Pottery Culture - the ones laying more to the east, like chocolate flint from the Holy Cross Mountains, or Volhynian/Prut flint from the Volhynian-Podolian Plateau were favoured. According

77 BÁcskay 1976; Biró 1998, 39; Korek 1989, 53.

78 T. Biró 1998, 50-51; KACZANOWSKA 1985.

79 KaCZanOWSKa 1985, 183.

80 T. Biró 1998, 65. 
to M. Kaczanowska and J. K. Kozłowski the diversity of the assemblages coming from different settlements may be an effect of regional and not diachronic reasons. ${ }^{81}$ In the southern part of the Great Hungarian Plain, for example at Öcsöd-Kováshalom and Hódmezővásárhely-Gorzsa, the east-west connections were dominant ${ }^{82}$ meaning a prevalence of diverse radiolarite types from Transdanubia, or Banat flint in these assemblages. In contrary, in the northern region, for example at Polgár-Bosnyákdomb, Polgár-Csőszhalom, and Berettyóújfalu-Herpály the northsouth connections had more significance, as attested by significant amounts of chocolate flint or Volhynian flint. ${ }^{83}$ At Polgár-Csőszhalom rather the tell part and not the external settlement is characterized by a prevalence of long-distance raw materials, which puts further emphasis on the complexity of each of the above-mentioned sites and communities.

\section{Conclusions}

The results of the ceramic and lithic analysis are congruent. Beside strong local roots, a part of the community of the Late Neolithic settlement at Pusztataskony seems to originate from an area with an early Lengyel identity and the ways of its expression. The otherways total lack of direct connections with Transdanubia, together with the strong connections reflected by the lithic as well as ceramic material with the cultural interference zone in the northeastern part of the Northern Mountains and Aszód make this area the probable place of more or less direct origin. The homogenous appearance of diverse Lengyel elements in the site's archaeological record suggests that the different identity and some ways of its expression were respected and accepted in Pusztataskony on a community level, embraced as part of an emerging or renewed group identity, while local practices were altered to suit all emerging demands. This included the local production of some vessel types of the Lengyel tradition, which probably had their own roles in symbolic communication. As the site possibly had connections with the southern distribution area of the Tisza culture, the appearance of such a secondary production point outside the Lengyel culture's core area might also raise questions about the origin and meaning of early Lengyel style vessels, interpreted until now usually as genuine imports (marking moreor-less direct connections with Transdanubian communities), appearing in the ceramic record of other coeval settlements in the Great Hungarian Plain. As from a stylistic point of view, this secondary production point, way out of the core area, seems to be rather (if not completely) isolated, one must calculate with a change in the dynamics of the appearing style regarding the tempo and direction of its evolution. Therefore, even if the stylistic integrity of the occurring types is seemingly maintained for some time, both their potential chronological and symbolic value must be determined independently (to deal with possible conservativism/alteration due to isolation), and must not be equalled with similar objects from the core area at face value.

\section{Acknowledgements}

We are indebted to Zsuzsanna Siklósi for her help with the evaluation of the radiocarbon data. We would like to thank Ágnes Király for making the elevation map she created available for this publication. We are also grateful to Zsófia Kondé for proofreading the manuscript.

81 KACZANOWSKA - KoZŁOWSKI 2015.

82 KaCZANOwsKa et al. 2009; StARnini et al. 2007; StARnini et al. 2015.

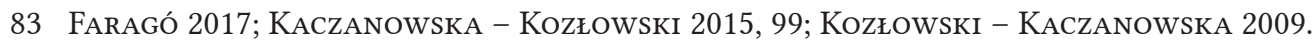




\section{References}

Anders A. - RAczky P. 2011: Háztartások és települési egység viszonya Polgár-Csőszhalom késő neolitikus lelöhelyén (The relation between households and settlement units at the Late Neolithic settlement of Polgár-Csőszhalom). Ósrégészeti Levelek 13, 78-101.

Anders, A. - Raczky, P. 2014: "A colourful message": a special grave of the Late Neolithic Tisza culture. In: Borhy, L. (ED.): Studia celtica, classica et romana Nicolae Szabó septuagesimo dedicata. Budapest, 193-202.

BANNER J. 1940: Hódmezővásárhely története a legrégibb időktől a magyar honfoglalásig. Hódmezővásárhely.

BANNER J. - KoREK J. 1949: Negyedik és ötödik ásatás a hódmezővásárhelyi Kökénydombon (Les campagnes IV et V des fouilles pratiquées au Kökénydomb de Hódmezővásárhely). Archaeologiai Értesitó 76, 9-25.

BÁcsKay, E. 1976: Early Neolithic chipped stone implements in Hungary. Dissertationes Archaeologicae 2/4. Budapest.

T. BIRó, K. 1998: Lithic implements and the circulation of raw materials in the Great Hungarian Plain during the Late Neolithic Period. Budapest.

Bronk Ramsey, C. 2009: Bayesian analysis of radiocarbon dates. Radiocarbon 51, 337-360.

Csalog, J. 1958: Das Wohnhaus E von Szegvár-Tüzköves. Acta Archaeologica Academiae Scientiarum Hungaricae 9, 95-114.

Diaconescu, D. 2014: Remarks on the chronology of the Lengyel culture in the western half of the Carpathian Basin based on the analysis of funerary assemblages. Prähistorische Zeitschrift 89, $12-39$.

FARAGÓ, N. 2017: Differences in the selection of raw materials at the site of Polgár-Csőszhalom, Northeast Hungary. Bulgarian e-fournal of Archaeology 7, 85-115.

Füzesi, A. - Seвőк, K. 2009: 556 Tiszabura-Ledence. In: Bencze, Z. - LőRInczy, G. - MrÁv, Zs. Rezi-Kató, G. - TomкA, G. - Wollák, K. (szerk.): Régészeti kutatások Magyarországon 2009 (Archaeological investigations in Hungary 2009). Budapest, 367-368.

FÜZesı, A. - SebőK, K. - V. Szabó, G. 2010: 519 Tiszabura-Ledence. In: Bencze, Z. - LőRInczy, G. Mráv, Zs. - Rezi-Kató, G. - TomKA, G. - Wolláк, K. (szerk.): Régészeti kutatások Magyarországon 2010 (Archaeological investigations in Hungary 2010). Budapest, 377-379.

Goldman, Gy. 1981: Battonya-Gödrösök és a tiszai kultúra kialakulása. Doktori disszertáció kézirata. Szeged.

L. HAJDÚ M. 2014: Újabb késő neolitikus lelőhelyek Borsod-Abaúj-Zemplén megyében - Newly discovered Late Neolithic archaeological sites in Borsod-Abaúj-Zemplén county, Hungary. A Herman Ottó Múzeum Évkönyve 53, 67-101.

L. HAJDÚ M. 2015: Késő neolitikus település Tiszatardosról (Borsod-Abaúj-Zemplén megye) (Late Neolithic settlement at Tiszatardos [Borsod-Abaúj-Zemplén County]). A Herman Ottó Múzeum Évkönyve 54, 79-111.

Hegedűs, K. - Makkay, J. 1987: Vésztő-Mágor. In: TÁlas, L. - Raczky, P. (eds.): The Late Neolithic of the Tisza Region. A survey of recent excavations and their findings: Hódmezővásárhely-Gorzsa, Szegvár-Tüzköves, Öcsöd-Kováshalom, Vésztö-Mágor, Berettyóújfalu-Herpály. Budapest-Szolnok, 85-104.

HoRvÁth, F. 2005: Gorzsa. Előzetes eredmények az újkőkori tell 1978 és 1996 közötti feltárásából (Gorzsa [Preliminary results of the excavation of the Neolithic tell between 1978-1996]). In: Bende, L. - LőRInczy, G. (szerk.): Hétköznapok Vénuszai. Hódmezővásárhely, 51-84.

Kaczanowska, M. 1985: Rohrstoffe, Technik und Typologie der neolithischen Feuersteinindustrien im Nordteil des Flussgebietes der Mitteldonau. Warszawa. 
Kaczanowska, M. - KozŁowski, J. K. - Sümegi, P. 2009: Lithic industries from the Öcsöd-Kováshalom tell-like settlement in Hungary. In: Draşovean, F. - Ciobotaru, D. L. - Maddison, M. (eds.): Ten years after: The Neolithic of the Balkans, as uncovered by the last decade of research. Proceedings of the conference held at the Museum of Banat on November 9th-10th, 2007. Bibliotheca Historica et Archaeologica Banatica 49. Timişoara, 125-149.

KaczAnowska, M. - KozŁowski, J. K. 2015: Raw materials circulation, organization of production and lithic technology in the Neolithic/Early Copper Age transition. In: HANSEN, S. - RaczKy, P. Anders, A. - Reingruber, A. (eds.): Neolithic and Copper Age between the Carpathians and the Aegean Sea. Chronologies and technologies from the 6th to the 4th Millennium BCE. International Workshop Budapest 2012. Archäologie in Eurasien 31, Bonn, 93-104.

Kalicz, N. 1985: Kókori falu Aszódon. Múzeumi Füzetek 32, Aszód.

Kalicz, N. 1998: Figürliche Kunst und bemalte Keramik aus dem Neolithikum Westungarns. Archaeolingua - Series Minor 10, Budapest.

Kalicz, N. 2008: Aszód: Ein gemischter Fundort der Lengyel- und Theiss-Kultur. Communicationes Archaeologicae Hungariae, 5-53.

KoReK, J. 1958: Lebő-halmi ásatás 1950-ben (The excavation at Lebő-halom in 1950). Archaeologiai Értesitő 83, 132-153.

Korek, J. 1973a: A tiszai kultúra. Doktori disszertáció kézirata. Budapest.

KoREK, J. 1973b: A Tisza II. vízlépcső területén 1964-72 között végzett ásatásokról. A Damjanich fános Múzeum Közleményei 33, 1-42.

Korek, J. 1987: Szegvár-Tüzköves. In: Tálas, L. - Raczky, P. (eds.): The Late Neolithic of the Tisza Region. A survey of recent excavations and their findings: Hódmezővásárhely-Gorzsa, Szegvár-Tüzköves, Öcsöd-Kováshalom, Vésztó-Mágor, Berettyóújfalu-Herpály. Budapest-Szolnok, 47-60.

Korek, J. 1989: Die Theiß-Kultur in der Mittleren und Nördlichen Theißgegend. Inventaria Praehistorica Hungariae 3. Budapest.

KovÁcs, K. 2013: A tiszai kultúra településtörténetének, belső kronológiájának és kapcsolatrendszereinek vizsgálata Északkelet-Magyarországon. $\mathrm{PhD}$ dissertation, manuscript. Budapest.

KozŁowski, J. K. - Kaczanowska, M. 2009: Polgár-Bosnyákdomb - Lithic assemblages. Archaeologiai Értesitó 134, 23-30.

Kreiter, A. - Kalicz, N. - KovÁcs, K. - SiKLósi, Zs. - ViKtorik, O. 2017: Entangled traditions: Lengyel and Tisza ceramic technology in a Late Neolithic settlement in northern Hungary. Journal of Archaeological Science: Reports 16, 589-603.

Kreiter, A. - Szakmány, Gy. - Kázmér, M. 2009: Ceramic technology and social process in Late Neolithic Hungary. In: Quinn, P. S. (ed.): Interpreting silent artefacts. Petrographic Approaches to Archaeological Ceramics. Oxford, 101-119.

Kreiter A.- Viktorik O. 2012: Lengyeli eredetủ hatások az Alföld kései neolitikumában. Pusztataskony-Ledence 1. feltárásának első eredményei. Appendix: Kerámiák petrográfiai vizsgálata Pusztataskony-Ledence 1. lelőhely, a tiszai kultúra települése és sírja anyagából (Petrographic analysis of ceramics from a grave and the settlement of the Tisza culture at Pusztataskony-Ledence 1). Archaeologiai Értesitő 137, 119-123.

Raczky, P. 1987: Öcsöd-Kováshalom. In: TÁLAs, L. - Raczky, P. (eds.): The Late Neolithic of the Tisza Region. A survey of recent excavations and their findings: Hódmezővásárhely-Gorzsa, Szegvár-Túzköves, Öcsöd-Kováshalom, Vésztö-Mágor, Berettyóújfalu-Herpály. Budapest-Szolnok, 61-84.

RACZKY, P. - ANDERs, A. 2006: Social dimensions of the Late Neolithic settlement of Polgár-Csőszhalom (Eastern Hungary). Acta Archaeologica Academiae Scientiarum Hungaricae 57, 17-33.

Raczky, P. - Anders, A. - Sebők, K. - Tóth, Zs. - Csippán, P. 2015: The Times of Polgár-Csőszhalom. Chronologies of human activities in a Late Neolithic settlement in Northeastern Hungary. In: Hansen, S. - Raczky, P. - Anders, A. - Reingruber, A. (eds.): Neolithic and Copper Age between the Carpathians and Aegaen Sea. Archäologie in Eurasien 31, 21-48. 
Raczky, P. - Domboróczki, L. - Hajdú, Zs. 2007: The site of Polgár-Csőszhalom and its cultural and chronological connections with the Lengyel culture. In: KozŁowski, J. K. - RAczky, P. (eds.): The Lengyel, Polgár and related cultures in the Middle/Late Neolithic in Central Europe. Kraków, 49-70.

RACZKY, P. - FÜZESI, A. 2018: Unusual clay artefacts and their imagery from the Late Neolithic settlement of Öcsöd-Kováshalom on the Great Hungarian Plain. In: ȚURCANu, S. - URsu, C. E. (eds.): Materiality and Identity in Pre- and Protohistoric Europe. Homage to Cornelia-Magda Lazarovici. Suceava, $145-170$.

Raczky, P. - Meier-Arendt, W. - Anders, A. - Hajdú, Zs. - Nagy, E. - Kurucz, K. - Domboróczki, L. Sebők, K. - Sümegi, P. - Magyari, E. - SzÁntó, Zs. - Gulyás, S. - Dobó, K. - BÁcskay, E. T. Biró, K. - Schwartz, CH. 2003: Polgár-Csőszhalom (1989-2000): Summary of the Hungarian-German excavations on a Neolithic settlement in Eastern Hungary. In: AsLAN, R. - BLum, St. - Kastl, G. - Schweizer, F. - Thum, D. (Hrsg.): Mauerschau. Festschrift für Manfred Korfman. Band 2. R. Greiner, Remshalden-Grubach, 833-860.

Raczкy, P. - SEвőк, K. 2014: The outset of Polgár-Csőszhalom tell and the archaeological context of a special central building. In: Forţı, S. - CînTAR, A. (eds.): ArheoVest II - in honorem Gheorghe Lazarovici. Interdisciplinaritate în Arheologie. Timişoara, 6 decembrie 2014. Szeged, 51-100.

Reimer, P. J. - Bard, E. - Bayliss, A. - Beck, J. W. - Blackwell, P. G. - Bronk Ramsey, C. - Buck, C. E. - Cheng, H. - Edwards, R. L. - Friedrich, M. - Grootes, P. M. - Guilderson, T. P. Haflidason, H. - Hajdas, I. - Hatté, Ch. - Heaton, T. J. - Hoffmann, D. L. - Hogg, A. G. Hughen, K. A.- Kaiser, K. F. - Kromer, B. - Manning, S. W. - Niu, M. - Reimer, R. W. Richards, D. A. - Scott, E. M. - Southon, J. R. - StafF, R. A. - Turney, C. S. M. - van DeR PLicht, J. 2013: IntCal13 and Marine13 radiocarbon age calibration curves 0-50,000 years cal BP. Radiocarbon 55, 1869-1887.

SeвőK, K. 2007: Ceramic forms of Polgár-Csőszhalom: a case study. In: KozŁowski, J. K. - RAczky, P. (eds.): The Lengyel, Polgár and related cultures in the Middle/Late Neolithic in Central Europe. Kraków, 97-116.

Sєво̋к K. 2012: Lengyeli eredetű hatások az Alföld kései neolitikumában. Pusztataskony-Ledence 1. feltárásának első eredményei (Influences of Lengyel origin in the Late Neolithic of the Great Hungarian Plain. First results from the excavations at Pusztataskony-Ledence 1). Archaeologiai Értesitó 137, 97-123.

SEво̋к, K. 2018a: Evolution of a design system in the eastern part of the Carpathian Basin. Transformations of the vessel-based human representations of the Middle Neolithic Szakálhát culture and the genesis of the Late Neolithic Tisza culture's 'textile' decoration. In: SAuvet, G. FrITZ, C. (eds.): Role of Art in prehistory - UISPP 2014. Quaternary International 491 (SI), $110-124$.

SЕво̋к, K. 2018b: On the possibilities of interpreting Neolithic pottery - Az újkőkori kerámia értelmezési lehetőségeiről. Dissertationes Archaeologicae 3/6, 13-42.

Sebők K. - Faragó N. - Hajdú Zs. - Anders A. - Raczky P. 2013: Egy különleges kút és leletei Polgár-Csőszhalom késő neolitikus településéről (An unusual well and its finds from the Late Neolithic settlement at Polgár-Csőszhalom). Archaeologiai Értesitó 138, 29-79.

SikLósi, Zs. 2013: Traces of social inequality during the Late Neolithic in the Eastern Carpathian Basin. Dissertationes Pannonicae 4/3, Budapest.

Starnini, E. - Voytek, B. A. - Horváth, F. 2007: Preliminary results of the multidisciplinary study of the chipped stone assemblage from the Tisza culture site of tell Gorzsa (Hungary). In: KozŁowsкi, J. K. - Raczкy, P. (eds.): The Lengyel, Polgár and related cultures in the Middle/Late Neolithic in Central Europe. Kraków, 269-278.

Starnini, E. - Szakmány, G. - Józsa, S. - Kasztovszky, Zs. - Szilágyi, V. - Maróti, B. - Voytek, B. Horváth, F. 2015: Lithics from the tell site Hódmezővásárhely-Gorzsa (Southeast Hungary): typology, technology, use and raw material strategies during the Late Neolithic (Tisza culture). 
In: Hansen, S. - Raczky, P. - Anders, A. - Reingruber, A. (eds.): Neolithic and Copper Age between the Carpathians and the Aegean Sea. Chronologies and technologies from the 6th to the 4th millennium BCE. International Workshop Budapest 2012. Archäologie in Eurasien Band 31. Bonn, 105-128.

TÁlas, L. - Raczky, P. (eds.) 1987: The Late Neolithic of the Tisza Region. A survey of recent excavations and their findings: Hódmezővásárhely-Gorzsa, Szegvár-Tüzköves, Öcsöd-Kováshalom, Vésztő-Mágor, Berettyóújfalu-Herpály. Budapest-Szolnok.

Trogmayer O. 1957: Ásatás Tápé-Lebőn (Ausgrabung auf Tápé-Lebő). A Móra Ferenc Múzeum Évkönyve, 19-60.

Trogmayer, O. 1962: X-XIII. századi magyar temető Békésen. A Móra Ferenc Múzeum Évkönyve, 9-38.

ZAlaI-GaÁl, I. 2010: Die soziale Differenzierung im Spätneolithikum Südtransdanubiens. Varia Archaeologica Hungarica 24, Budapest. 